\title{
Index for Volume 94 of Plant Disease
}

AUTHOR AND SUBJECT INDEX. Page numbers of errata are in italic. N indicates disease note.

Abad, J. A., 481N, 782N

Abad-Campos, P., 278N, 534

Abbasi, M., 375N

Abdourhamane, I. K., 378N, 923N

Abelleira, A., 635N

Abelmoschus esculentus (okra)

Okra yellow mosaic Mexico Virus in, in

U.S., 924N

Sclerotium rolfsii on, in Ivory Coast, 1379N

Abies spp.

Heterobasidion spp. on, annosus root disease and, 115

Phytophthora ramorum on, in California, $1170 \mathrm{~N}$

Abo, K., 1378N

Acanfora, N., 924N

Aceria tosichella (wheat curl mites), Wheat streak mosaic virus in wheat and, water-use efficiency and soil water content, 771

Achigar, R., 786N

Acidovorax spp.

on betelvine in Taiwan, $1065 \mathrm{~N}$

on creeping bentgrass in U.S., $922 \mathrm{~N}$

Acosta-Pardini, J., 388

Actinidia deliciosa (kiwi), Botryosphaeria

dothidea on, in Greece, 1503N

Adaskaveg, J. E., 1485

Adhikari, T. B., 229

Adkins, S., 542

African citrus psyllid. See Trioza erytreae

Agindotan, B. O., 480N

Agonis flexuosa (dwarf willow myrtle), Cylindrocladium pauciramosum on, in Italy, $274 \mathrm{~N}$

Agrobacterium rhizogenes, on blueberry in Argentina, 1064N

Agrobacterium rubi, on blueberry in Argentina, $1064 \mathrm{~N}$

Agropyron repens (couch grass), Epichlö̈ bromicola on, in Poland, $1372 \mathrm{~N}$

Agrostis stolonifera (creeping bentgrass)

Acidovorax spp. on, in U.S., 922N

Colletotrichum cereale on

azoxystrobin resistance, 751

$\beta$-tubulin 2 gene, thiophanate-methyl resistance and, 207

Sclerotinia homoeocarpa on, fungicides for control of, 596

Waitea circinata from, in British Columbia, $277 \mathrm{~N}$

Aguín Casal, O., 273N

Ahonsi, M. O., 480N

Aiello, D., 125N, 131N, 274N, 275N, 483N, $486 \mathrm{~N}, 1509 \mathrm{~N}$

Aime, M. C., 272N, 380N, 478N, 636N

Aino, M., 812

Akbas, B., 641N

Aké, S., 1378N

Akiba, M., 358

Alabi, O. J., 478N

Alaniz, S., 534

Alberti, I., 1070N

Alcea rosea (hollyhock), malva vein clearing

virus in, in Germany, 276N, Cover photo:

February

Alder, red. See Alnus rubra

Alexander, B. J. R., 781N

Alexander, H. M., 492

Alfalfa, as source of Xylella fastidiosa vectors, and diseases in California, 827

Alfalfa mosaic virus (AMV)

in lavender in Italy, $924 \mathrm{~N}$

in potato, cDNA microarray for detection of, 1248

in soybean in Tennessee, $1505 \mathrm{~N}$
Alfaro-Fernández, A., 1264N

Algaecides, Phytophthora capsici zoospore infectivity in cucumber and, 54

Ali, I., 276N

Ali, S., 229

Alippi, A. M., 487N, 1064N

Ali-Shtayeh, M. S., 640N

Alkhader, M. Y., 640N

Allium spp.

A. cepa (onion)

Enterobacter cloacae on: postharvest curing parameters and, 1425, Cover photo: December; and resistance, 236

Iris yellow spot virus in: in Hawaii, $1508 \mathrm{~N}$; in Mauritius, $1373 \mathrm{~N}$; in Uruguay, $786 \mathrm{~N}$

Leveillula taurica on, in Iran, $280 \mathrm{~N}$

Pantoea ananatis on, in New York, $916 \mathrm{~N}$

A. porrum (leek), Iris yellow spot virus in, in

Sri Lanka, 1070N

A. sativum (garlic)

Fusarium proliferatum on, in Spain, $277 \mathrm{~N}$

Iris yellow spot virusion, in India, 1066N Shallot latent virus in, in Argentina, 915N Stemphylium solani in, phytotoxin from, 1225

Almond. See Prunus dulcis

Alnus rubra (red alder), Phytophthora alni subsp. alni on, in Spain, 273N

Alpinia purpurata (flowering ginger), Banana

bract mosaic virus in, in Hawaii, 921N

Alternaria spp.

A. alternata

on Bupleurum chinense in China, 918N in persimmon in Turkey, $1069 \mathrm{~N}$ resistance to in sorghum, in mini-core germplasm collection, 439

on tangerines in China, $375 \mathrm{~N}$

A. dauci, on carrot, aggressiveness and fungicide sensitivity, 405

on Eriobotrya japonica in Taiwan, $481 \mathrm{~N}$

A. radicina, on carrot seed from New

Zealand, $1168 \mathrm{~N}$

Alvarez, A. M., 521

Álvarez, L. A., 534

Alves, J. L., 278N

Amatulli, M. T., 788N, 1066N

Amenduni, M., 1176

Ames, K. A., 83

Amiri, A., 737, 1366, 1511N

Ammar, K., 1068N

Ammonium salts, and Phytophthora sojae in soybean, 758

AMV. See Alfalfa mosaic virus

An, F., 977

Ananas spp. (pineapple)

pineapple fruit collapse and, bacteria and

yeast associated with, $1509 \mathrm{~N}$

pineapple mealybug wilt-associated viruses in, 196

Anders, M. M., 570

Anderson, K. K., 1167N

Angadi, S., 638N

Angelica acutiloba, Fusarium solani in, in Taiwan, $1164 \mathrm{~N}$

Angelini, E., 1355

Anisogramma anomala, on hazelnut in New Jersey, $1265 \mathrm{~N}$

Annosus root disease, Heterobasidion spp., in southern Rocky Mountains and adjoining states, 115

Anther smut, Microbotryum violaceum on Silene latifolia, Cover photo: May
Anthurium andraeanum

Calonectria ilicicola on, in Iran, $278 \mathrm{~N}$

Xanthomonas axonopodis pv. dieffenbachiae

in, resistance to, 1243

Antoniou, P. P., 1156

Antonopoulos, D. F., 613

Aoki, T., 1411

Aphanomyces euteiches, on lentil in Idaho, $480 \mathrm{~N}$

Apioplagiostoma populi, on poplars in Canada, $377 \mathrm{~N}$

ApLV. See Apricot latent virus

ApMV. See Apple mosaic virus

Apple. See Malus domestica

Apple mosaic virus (ApMV), in plum in Turkey, $641 \mathrm{~N}$

Apple replant disease, seed meal soil amendments for control of, 835

Apple scab, Venturia inaequalis in apple and crabapple in Indiana, benzimidazole resistance, 744

Apple stem pitting virus (ASPV), in Bartlett pear in Argentina, $488 \mathrm{~N}$

Apricot. See Prunus armeniaca

Apricot latent virus (ApLV), on apricot in Spain, 275N

Apscaviroid spp., on Moro blood sweet orange in Iran, $129 \mathrm{~N}$

Arabis mosaic virus (ArMV), on grapevines in Spain, 635N

Arachis hypogaea (peanut) evaluation of treatments for control of seedling diseases in, 445

Sclerotium rolfsii and Cercospora arachidicola in, night spraying of fungicides and, 676, 683

Arachis hypogaea (peanut), Tomato spotted wilt virus in, planting date and cultivar interactions, 891

Arai, M., 329

Araucaria araucana, Armillaria tabescens in, in Mexico, 784N

Arceuthobium spp. (mistletoe)

A. abietinum (white fir dwarf mistletoe), on

Mexican spruce in Mexico, 635N

A. blumeri (Blumer's dwarf mistletoe), on

Pinus ayacahuite in Mexico, $377 \mathrm{~N}$

A. cyanocarpum (limber pine dwarf mistletoe), on sugar pine in California, $134 \mathrm{~N}$

A. globosum (rounded dwarf mistletoe), on

Pinus durangensis in Mexico, 377N

Areca catechu (arecanut palm), phytoplasma infection of in India, 1376N

Arecanut palm. See Areca catechu

Arguello-Astorga, G., 1266N

Ariss, J. J., 1195

Armengol, J., 278N, 374N, 396, 1170N, 1176

Armillaria spp.

A. gallica, on several new hosts in Hawaii, $1503 \mathrm{~N}$

A. tabescens, in Araucaria araucana in

Mexico, $784 \mathrm{~N}$

ArMV. See Arabis mosaic virus

Arocha-Rosete, Y., 916N

Arrebola, E., 244

Arrowroot. See Maranta arundinacea

Artemisia tridentata (sagebrush), Puccinia

similis on, in Idaho and Oregon, 380N

Arthur, J., 766

Artichoke. See Cynara cardunculus

Arundale, R., 480N

Ascochyta pisi, on pea in South Dakota, 789N, Cover photo: June

Asgari, B., 642N

Asian citrus psyllid. See Diaphorina citri

Asian pear. See Pyrus pyrifolia 
Asian soybean rust (SBR), understanding risk in different regions of world, 796

Asmus, G. L., 1022

Asparagus officinalis, Pleospora herbarum on, environment and airborne spore concentrations, 843

Attar, N., 1068N

Augusto, J., 676, 683

Avena sativa (oat)

Fusarium proliferatum in, in Argentina, 783N

Puccinia coronata f. sp. avenae in, and broad-spectrum resistance, 1405, Cover photo: December

Averell, R. M., 1379N

Azalea. See Rhododendron spp.

Azarenko, A. N., 345

Azoxystrobin

for Colletotrichum cereale in turf grasses, resistance to, 751

processing sweet corn and, 213

for Sclerotium rolfsii and Cercospora arachidicola in peanut, night spraying and, 676, 683

Azpilicueta, A., 280N

Babesia taaci, and Tomato yellow leaf curl Thailand virus on pepper in Taiwan, 637N Bacci, L., 1076

Bacharis, C., 1314

Bacterial wilt disease, Ralstonia solanacearum on Solanum spp., 372N

Bactericera cockerelli (potato psyllid),

Candidatus Liberibacter psyllaurous and,

$376 \mathrm{~N}$, cover photo: March

Baeza-Montañez, L., 380N

Bai, Q., 915N

Baiswar, P., 126N

Bakanae disease, Fusarium andiyazi on rice in Italy, $1070 \mathrm{~N}$

Baker, C., $487 \mathrm{~N}$

Baker, C. A., 378N

Baker, C. J., $1063 \mathrm{~N}$

Bakonyi, J., 1062N

Balatti, P. A., 1064N

Balbalian, C., 634N

Balbalian, C. J., 643N

Balesdent, M. H., 791N

Balestra, G. M., 382N

Balsam pear. See Momordica charantia (balsam pear)

Ban, T., 335

Banana. See Musa spp.

Banana bacterial wilt (BBW), in banana, PCR assay for detection of, 109

Banana bract mosaic virus (BBrMV), in

flowering ginger in Hawaii, $921 \mathrm{~N}$

Banana Xanthomonas wilt $(B X W)$, in banana,

PCR assay for detection of, 109

Bananej, K., 788N

Bani Hashemian, S. M., 129N

Banniza, S., 1219

Baranwal, V. K., 636N

Barbasso, D., 1170N

Barbetti, M. J., 563, 1041

Barbosa, J. C., 374N

Barker, I., 510

Barley. See Hordeum vulgare

Barlow, T., $132 \mathrm{~N}$

Barreto, R. W., 278N

Bartlett pear. See Pyrus communis

Bartz, F. E., 515

Barutçu, E., 1448

Basil. See Ocimum basilicum; Ocimum minimum

Bassanezi, R. B., 283

Bastianel, M., 283

Bates, C., $918 \mathrm{~N}$

Battany, M., 717

BBrMV. See Banana bract mosaic virus

BCMV. See Bean common mosaic virus

Bean. See Phaseolus vulgaris; Vigna unguiculata subsp. sesquipedalis

Bean common mosaic necrosis virus (BCMNV), in bean from Iran, $127 \mathrm{~N}$

Bean common mosaic virus (BCMV), in yardlong beans in Indonesia, $478 \mathrm{~N}$

Bean pod mottle virus (BPMV), 265

Bean yellow mosaic virus (BYMV), in clover in Alaska, 361

Beasley Jr., J. P., 898

Beckerman, J. L., 744

Beech, European. See Fagus sylvatica

Beer, S. V., $916 \mathrm{~N}$

Beet curly top virus (BCTV), immunodetection of, 972

Beet leafhopper. See Circulifer tenellus

Beet mild curly top virus (BMCTV) immunodetection of, 972 in tomato, curly top disease and, 99

Beet mosaic virus (BtMV), in chickpea in Tunisia, $1068 \mathrm{~N}$

Beet necrotic yellow vein virus (BNYVV), in spinach in California, 640N

Beet severe curly top virus (BSCTV), in tomato, 99

Begomovirus spp., in wild Solanum accessions, multiple resistance to, 179

Belisario, A., 134N, 484N, 791N

Bellardi, M. G., 924N

Bellflower. See Campanula lactiflora

Belonolaimus longicaudatus, on soybean in Delaware, $133 \mathrm{~N}$

Belton, M., 1367

Bemisia argentifolii (whitefly), and Cucurbit chlorotic yellows virus in cucurbits in Taiwan, $1168 \mathrm{~N}$

Bemisia tabaci (whitefly) and Cucurbit yellow stunting disorder virus on melon in China, $485 \mathrm{~N}$

and Sweet potato chlorotic stunt virus in sweetpotato, 510

and Tomato chlorosis virus in sweet pepper in Brazil, 374N

Bender, C. M., 381N, 784N

Benimadhu, S., 1069N

Benimadhu, S. P., 1261N, 1373N

Benlioglu, K., 923N

Bennett, Rebecca S., 1469

Benomyl, Botrytis cinerea on raspberry in Serbia, and resistance, $486 \mathrm{~N}$

Benzimidazole, Venturia inaequalis in apple and crabapple in Indiana, resistance to, 744

Berbegal, M., 374N, 396, 534, 1170N, 1176

Berder, J., 1068N

Bergstrom, G. C., 1151

Berner, D. K., $918 \mathrm{~N}$

Berry, S. A., $125 \mathrm{~N}, 265$

Bertaccini, A., 916N

Bertetti, D., 129N, 130N, 380N, 638N, 788N, $917 \mathrm{~N}, 1071 \mathrm{~N}, 1171 \mathrm{~N}$

Bertolini, E., $635 \mathrm{~N}$

Beserra Jr., E. A., 1206

Bester, L., 478N

Bester, W., 1063N

Beta vulgaris (sugar beet)

Cercospora beticola in fungicide sensitivity and, 1272, Cover photo: November

PCR-based detection of in soils, 1100 curtoviruses in, immunodetection of, 972 Rhizopus stolonifer and Rhizoctonia solani in, 504

Betelvine. See Piper betle

Bettiga, L. J., 717

Bienapfl, J. C., 1069N

Biggs, A. R., 812

Big-vein disease, Olpidium virulentus in lettuce and, 563

Biological control

Bipolaris sp. for Japanese stiltgrass, 807

changing models for commercialization and implementation of, 928

Colletotrichum hanaui for hairy crabgrass in
China, $1510 \mathrm{~N}$

Coniothyrium minitans for Sclerotinia sclerotiorum in lettuce, 1118

HrpNEa protein of Erwinia amylovora, for Pectobacterium carotovora subsp. carotovora resistance in Chinese cabbage, 1441

Puccinia jaceae var. solstitialis for yellow starthistle, in California, 174

Bipolaris spp.

B. cactivora, on pithaya in Florida, $1506 \mathrm{~N}$

B. oryzae, on switchgrass in Mississippi, $643 \mathrm{~N}$

B. setariae, on cassava in China, $919 \mathrm{~N}$

on Japanese stiltgrass, 807

Bird of paradise. See Strelitzia reginae

Bischoff, J. F., 1169N

Bischofia javanica, Phellinus noxius on in

Ryuku Islands (Japan), 358

Bitter gourd. See Momordica charantia

Bitternut hickory. See Carya cordiformis

Bivona, L., 1172N

Black, M. C., 1377N

Blackberry. See Rubus spp.

Blancard, D., 633N

Blanco-López, M. A., 382N

Blenis, P. V., 1238

Blephilia hirsuta, Cucumber mosaic virus in, in North America, 1070N

Blodgett, J. T., 115

Blueberry. See Vaccinium corymbosum

Blueberry red ringspot virus (BRRV), in

blueberry in Czech Republic, 1071N

Bluegrass, annual. See Poa annua

Bluhm, B. H., 381N

Blumer's dwarf mistletoe. See Arceuthobium

blumeri (Blumer's dwarf mistletoe)

BNR. See Rhizoctonia AG-A (binucleate)

Bock, C. H., 725

Bødker, L., 432

Boehmeria nivea (ramie, China grass),

Colletotrichum gloeosporioides on, in China, $1508 \mathrm{~N}$

Boiteux, L. S., 179, 781N

Bokhari, N., 1163N

Boland, G. J., 952

Boldini, J., 1170N

Bolou Bi, B. A., 1379N

Bonasera, J. M., 916N

Bonello, P., 1026

Bonfim Jr., M. F., 790N

Borodynko, N., 633N, 920N

Borth, W. B., 196, 641N, 921N, 1508N

Boscalid

Botrytis spp. on apple, resistance to, 604

Sclerotinia homoeocarpa on creeping

bentgrass, 596

Botermans, M., $791 \mathrm{~N}, 920 \mathrm{~N}$

Botryosphaeria spp.

$B$. dothidea

on kiwi in Greece, $1503 \mathrm{~N}$ on mango in Taiwan, $128 \mathrm{~N}$

B. ribis, on currant in U.S., 1283

on grapevine, temperature and conidial germination, 1476

on grapevine in California, spore-trapping studies, 717

Botrytis spp.

B. cinerea

on apple, resistance to pyraclostrobin and boscalid, 604

on French lavender in Italy, 380N

on raspberry in Serbia, and resistance, $486 \mathrm{~N}$ resistance to multiple fungicides, 551 on table grapes, fungicides for control of, 250

gray mold of strawberry from, 284, Cover photo: March

Boucher, A., 1384

Bougainvillea glabra (paper flower), Fusarium

oxysporum on, in Italy, $483 \mathrm{~N}$

Bowen, C. R., 361 
Bowman, B. C., 1361

Boxwood. See Buxus rotundifolia

Boydston, R. A., 918N

Boyer, C., 1069N, 1264N

Boykin, D. L., 1035

BPMV. See Bean pod mottle virus

Bradford pear. See Pyrus calleryana

Bradley, C. A., 83, 273N, 477N, 480N, 1262N

Branched broomrape. See Orobanche ramosa

Brannen, P. M., 737, 1366

Brannigan, K., 99

Brassica spp.

B. campestris L. (Chinese cabbage),

Pectobacterium carotovora subsp. carotovora in, HrpNEa protein of Erwinia amylovora for resistance against, 1441

B. juncea, seed meal soil amendments from, apple replant disease and, 835

B. napus (canola) Sclerotinia sclerotiorum in, in Texas, $791 \mathrm{~N}$

Sclerotinia sclerotiorum on, factors enhancing carpogenic germination of sclerotia, 1041

B. napus (rape), Pseudomonas viridiflava in in South Korea, 1164N

B. oleracea var. capitata (cabbage) Leptosphaeria maculans on, in Mexico, $791 \mathrm{~N}$

Pseudomonas syringae pv. alisalensis on, in South Carolina, $132 \mathrm{~N}$

B. oleracea var. gemmifera (Brussels sprouts) Mycosphaerella brassicicola in, risk assessment for, 851

Pseudomonas cannabina pv. alisalensis in, in California, $1375 \mathrm{~N}$

B. oleracea var. italica (broccoli),

Pseudomonas syringae pv. alisalensis on, in South Carolina, 132N

mustards, Turnip mosaic virus in, resistance phenotypes, 1290, Cover photo: November

Xanthomonas campestris pv. campestris on, in Nepal, 298

Breithaupt, J., 482N

Brenneman, T. B., 676, 683, 898

Brenneria quercina, pathovar of, in white lupine, 1431

Bressiani, J., 1170N

Brevipalpus spp., citrus leprosis and, 284, Cover photo: March

Breytenbach, J. H. J., 244

Briggs, A., 482N

Brlansky, R. H., 528, 1200

Broccoli. See Brassica oleracea var. italica

Broders, K. D., 952

Bronze leaf disease, on poplar in Canada, Apioplagiostoma populi and, 377N

Brooks, S. A., 570

Broschat, T. K., 31

Brown, C. R., $918 \mathrm{~N}$

Brown, J., 835

Brown, J. K., 376N, 917N, 924N

Brown, K. L., 372N

Brown-Rytlewski, D. E., 1164N

BRRV. See Blueberry red ringspot virus

Bruez, E., 1476

Brussels sprouts. See Brassica oleracea var. gemmifera

Bruton, B. D., 92

Bryson, P. K., $1511 \mathrm{~N}$

BtMV. See Beet mosaic virus

Bubici, G., 1176

Budziszewska, M., 920N

Buell, C. R., 311

Bugiani, R., 709

Bulajiæ, A., 703

Bull, C. T., $1375 \mathrm{~N}$

Bünter, M., 643N

Bupleurum chinense, Alternaria alternata on, in China, 918N

Burger, J. T., 373N
Burgos, M. R. G., 311

Buriola, J. E., 789N

Burkholderia gladioli, in Dracaena reflexa, $781 \mathrm{~N}$

Burnett, A., 126N

Burnett, A. L., 1000

Bursaphelenchus spp.

on Pinus densiflora in Korea, 922N

on Scots pine, watering regime and, 1055

Bustamante, E., 940

Butternut. See Juglans cinerea

Buxus rotundifolia (boxwood), Phytophthora

citrophthora on, in Italy, $272 \mathrm{~N}$

Byamukama, E. Z., 167

BYMV. See Bean yellow mosaic virus

BYNVV. See Beet necrotic yellow vein virus

Cabaleiro, C., $635 \mathrm{~N}$

Cabbage. See Brassica campestris L.; Brassica

oleracea var. capitata

Cabos, R., 521

Cabral, P. G. C., $1378 \mathrm{~N}$

Cacciola, S. O., 1372N, 1374N

Caesar, A. J., 1166N

Caesar-TonThat, T. C., 1100, 1166N

Caffi, T., 709

Cafrune, E. E., $915 \mathrm{~N}$

Çaglayan, K., 1448

Cai, J.-M., 916N, 919N

Calabash gourd. See Lagenaria siceraria

Calcium, for Phytophthora sojae on soybean, 812

Calderon, J., 482N

California red fir. See Abies magnifica

Caliskan, O., 1448

Callery pear. See Pyrus calleryana

Calonectria ilicicola, on Anthurium

andraeanum in Iran, $278 \mathrm{~N}$

Calosphaeria pulchella, 1167N

Câmara, M. P. S., $1506 \mathrm{~N}$

Cambra, M. A., $786 \mathrm{~N}$

Caminero, C., $128 \mathrm{~N}$

Campa, A., 885

Campanula lactiflora (milky bellflower),

Phoma sp. on, in Italy, 638N

Campbell, R., 634N

Canaday, C. H., 758

Canadian goldenrod (Solidago canadensis). See Solidago canadensis

Canarygrass, hood. See Phalaris paradoxa

Candida sp., on pineapple in Brazil, 1509N

Candidatus spp.

$\mathrm{Ca}$. Liberibacter africanus, in citrus, in South Africa, 244

$\mathrm{Ca}$. Liberibacter asiaticus

lack of evidence of transmission through seeds of affected fruit, 1195

in Murraya spp., 528

on satkara in India, $375 \mathrm{~N}$

in sweet orange in Ethiopia, 482N

from sweet orange, Mexican lime, and Asian citrus psyllid, 781N

$\mathrm{Ca}$. Liberibacter psyllaurous on potato in Honduras, $376 \mathrm{~N}$ on tomatoes in Arizona, $376 \mathrm{~N}$, cover photo: March

Ca. Liberibacter solanacearum on carrots in Europe, 639N, Cover photo: May

on field tomatoes in U.S., $481 \mathrm{~N}$

on potato, zebra chip disease and, 659

$\mathrm{Ca}$. Phytoplasma asteris, on showy rattlebox

in India, $1265 \mathrm{~N}$, Cover photo: October

$\mathrm{Ca}$. Phytoplasma asteris'-related strain, in peach in Canada, $916 \mathrm{~N}$

Ca. Phytoplasma pyri, on pear in Canada, 634N

Ca.Phytoplasma aurantifolia, on rose

pelargonium in Australia, $1264 \mathrm{~N}$

Candresse, T., 477N, 633N

Cannon, P., 784N

Canola. See Brassica napus

Canyon live oak. See Quercus chrysolepis

Cao, M. J., $922 \mathrm{~N}$
Capik, J., 1265N

Caprile, J., 1167N

Capsicum chlorosis virus (CaCV), in tomato in

Taiwan, $1263 \mathrm{~N}$

Capsicum frutescens (pepper), Tobacco curly shoot virus on, in China, $637 \mathrm{~N}$

Capsicum spp.

C. аппиит (pepper)

Fusarium solani in, in Trinidad, $1375 \mathrm{~N}$

Pepper veinal mottle virus on, in Mali, $378 \mathrm{~N}$

Phytophthora capsici in, 24, 697

Sclerotium rolfsii on, in southern Spain, $280 \mathrm{~N}$

Tomato chlorosis virus in, in Brazil, 374N

Tomato spotted wilt virus in, in Taiwan, $920 \mathrm{~N}$

Tomato yellow leaf curl Thailand virus on, in Taiwan, $637 \mathrm{~N}$

Tomato yellow leaf curl virus and

Tomato chino La Paz virus in, in

Mexico, $1266 \mathrm{~N}$

Tomato yellow leaf curl virus in, in Guatemala, $482 \mathrm{~N}$

Xanthomonas arboricola on, in Korea, $271 \mathrm{~N}$

Colletotrichum spp. in, differential reactions to, 306

Xanthomonas euvesicatoria on, in Grenada, $1264 \mathrm{~N}$

Xanthomonas spp. in, genetic and pathological diversity in, 993

Carbendazim

Botrytis cinerea and, multiple resistance and, 551

Gibberella zeae in wheat, resistance to, 1137

Cardenas-Conejo, Y., 1266N

Cardin, L., 790N

Carica papaya (papaya)

Colletotrichum capsici on, in Florida, 1065N

Colletotrichum magna on, in Brazil, 1506N

Papaya lethal yellowing virus in, 1206,

Cover photo: October

Carmona, M. A., 1411

Carr, E. A., $916 \mathrm{~N}$

Carroll, A. G., $1168 \mathrm{~N}$

Carrot. See Daucus carota

Carrot psyllid. See Trioza apicalis

Carson, M. L., 1405

Carya spp.

C. cordiformis (bitternut hickory),

Ceratocystis smalleyi on, in north-central and northeastern U.S., $277 \mathrm{~N}$

C. illinoinensis (pecan), Xylella fastidiosa in, insect transmission of, 465

Caryocar brasiliense (pequi), Pratylenchus zeae in, in Brazil, 790N

Casaurina equisetifolia, Phellinus noxius on in

Ryuku Islands (Japan), 358

Cassava. See Manihot esculenta

Castanea sativa (chestnut), Phytophthora

pseudosyringae in, in Italy, $1068 \mathrm{~N}$

Castello, I., 125N, 275N, 486N

Castillo, P., 148

Castlebury, L. A., 279N, 293

Catalano, L., $482 \mathrm{~N}$

Catharanthus roseus (vinca)

as host of Coleosporium plumeriae rust on

Plumeria spp., 272N

Phytophthora tropicalis on, in Virginia, 274N

Cauich-Pech, S. O., 1376N

CBCVd. See Citrus bark cracking viroid

CCYV. See Cucurbit chlorotic yellows virus

(CCYV)

Cebreros, R. D. Núñez-, 1376N

Cebrián, M. C., 1264N

Celosia plumosa, Iresine viroid 1 in, in Netherlands, $920 \mathrm{~N}$

Centaurea solstitialis (yellow starthistle) Puccinia jaceae var. solstitialis on, in California, for biological control, 174 
Center, T. D., $1165 \mathrm{~N}$

Cephalosporium maydis, on corn in Portugal and Spain, 379N

Ceratocystis paradoxa, on coconut in Taiwan, $487 \mathrm{~N}$

Ceratocystis smalleyi, on butternut hickory, in north-central and northeastern U.S., $277 \mathrm{~N}$

Cercospora spp.

C. arachidicola, in peanut, night spraying of fungicides and, 676, 683

C. beticola on sugar beet, fungicide sensitivity and, 1272, Cover photo: November in sugar beet, PCR-based detection of in soils, 1100

C. zeae-maydis, herbicides on corn with simulated hail damage and, 83

Cereal cyst nematode. See Heterodera filipjevi

Cereals, soilborne pathogens of in irrigated cropping system, 61

Cerny, K., 272N

Cerotoma trifurcata (bean leaf beetle), Bean pod mottle virus in soybean and, insectresistance and, 265

CEVd. See Citrus exocortis viroid

Cgebm W., 87

Chaijuckam, P., 690, 986

Chalara fraxinea, on common ash in Italy, 133N

Chamaerops humilis L. (Mediterranean fan palm), Rhizoctonia solani AG-4 on in Italy, $125 \mathrm{~N}$

Chandeysson, C., 1378N

Chandra, S., 126N

Chang, S. T., 131N

Chao, C. H., 131N, 1062N

Chapman, K. S., 744

Charchar, J. M., 179, 781N

Chastagner, G. A., $1170 \mathrm{~N}$

Chávez-Medina, J. A., 388

Chen, C., 87, 1200

Chen, C. M., $1165 \mathrm{~N}$

Chen, C. Y., 481N

Chen, C.-J., 551

Chen, H. Q., $918 \mathrm{~N}$

Chen, J., 1508N

Chen, J. C., 75

Chen, J. Y., 1503N

Chen, L. -F., 99

Chen, L. F., 482N

Chen, R. S., 128N

Chen, R.-S., 787N

Chen, S. F., 1143

Chen, S. S., $481 \mathrm{~N}$

Chen, T.-C., $1168 \mathrm{~N}$

Chen, W. Q., 1163N

Chen, X. Y., 1508N

Chen, Y., 551

Chen, Y. Y., 485N

Cheng, Y.-H., 920N, 1263N

Chern, L. L., 1164N

Cherry. See Prunus avium; Prunus cerasus

Cherry leaf roll virus (CLRV)

in nasturtium on Amsterdam Island, 477N

in sweet cherry in Washington, 1067N

in wild potato in South America, 782N

Chestnut. See Castanea sativa

Chicau, G., 1170N

Chickpea. See Cicer arietinum

Chickpea chlorotic stunt virus (CpCSV), in

chickpea in Iran, 788N

Chicory, Witloof. See Cichorium intybus

Chillet, M., 648

Chilvers, M. I., 1164N

China grass. See Boehmeria nivea

Chinese cabbage. See Brassica campestris L.

Chinese peony. See Paeonia lactiflora

Chinese weeping cypress. See Cupressus funebris

Chinestra, S. C., 1188

Chiroleu, F., 993

Chitrampalam, P., 1118
Chloride salts, and Phytophthora sojae in soybean, 758

Chlorothalonil, Sclerotinia homoeocarpa in creeping bentgrass, 596

Choi, G. S., 792N

Christensen, C. B., 432

Christiano, R. S. C., 1213

Christopher, S. J., 1341

Chrysoporthe cubensis, in Eucalyptus spp. and Syzygium cumini, 1143

Chung, B. N., 792N

Chung, Y.-J., 922N

Cicer arietinum (chick pea, garbanzo, gram) Beet mosaic virus in, in Tunisia, $1068 \mathrm{~N}$ Chickpea chlorotic stunt virus in, in Iran, $788 \mathrm{~N}$

chickpea rust on, new hosts, 293

Cichorium intybus (witloof chicory)

Phytophthora tentaculata on, in Italy, 1504N

CIMMYT. See International Maize and Wheat Improvement Center

Cinnamon oil, Rhizoctonia oryzae-sativae in rice and, 986

Circulifer tenellus (beet leafhopper) curtoviruses and, immunodetection of, 972 monitoring for curly top disease in tomatoes and, 99

and Spinach severe curly top virus in Arizona, $917 \mathrm{~N}$

Cirulli, M., 1176

Citrullus lanatus (watermelon)

Cucurbit chlorotic yellows virus in, in Taiwan, $1168 \mathrm{~N}$

Fusarium oxysporum f. sp. niveum race 3 and, 92

Monosporascus cannonballus on, in Brazil, $278 \mathrm{~N}$

Citrus

Candidatus spp. in, in South Africa, 244

Mandarin rind disorder of, etiology and management in California, 1485

Spiroplasma citri on, titer and disease severity, 75

Citrus aurantifolia (key lime), Geotrichum citriaurantii on, in Mexico, 488N

Citrus bark cracking viroid $(\mathrm{CBCVd})$, in citrus in China, 922N

Citrus exocortis viroid (CEVd), in grapevine in China, $1071 \mathrm{~N}$

Citrus leprosis virus (CiLV-C), overview of,

284, Cover photo: March

Citrus macroptera (satkara), Candidatus

Liberibacter on, $375 \mathrm{~N}$

Citrus psyllid. See Diaphorina citri

Citrus reticulata (tangerines), Alternaria alternata on, in China, $375 \mathrm{~N}$

Citrus sinensis (Moro blood sweet orange), citrus viroid V on, in Iran, 129N

Citrus stubborn disease (CSD), Spiroplasma citri titer and, 75

Citrus viroid $V(\mathrm{CVd}-\mathrm{V})$ in citrus in China, $922 \mathrm{~N}$ on Moro blood sweet orange in Iran, 129N

Ciurlino, R., $1169 \mathrm{~N}$

Clark, R., 99

Clavibacter michiganensis subsp. nebraskensis, in corn in Minnesota, 1064N

Clement, D. L., 279N

Cleveland, S., 1132

Clonostachys rhizophaga, on Dendrocalamus giganteus in Mozambique, 372N

Clover, G. R. G., 479N

Clubroot, in planta quantification of

Plasmodiophora brassicae and, 432

Coast live oak. See Quercus agrifolia

Coates, W. W., $1167 \mathrm{~N}$

Cocos nucifera (coconut)

16SrXI group phytoplasma in, in India, 636N Ceratocystis paradoxa on, in Taiwan, $487 \mathrm{~N}$

Coertze, S., 478N

Coffey, M. D., 1163N
Coleosporium plumeriae, on Plumeria spp., in Louisiana and Malaysia, 272N

Coleus blumei, Tobacco etch virus in, in U.S., $921 \mathrm{~N}$

Colletotrichum spp.

C. acutatum on blackberry in Brazil, 1378N on mung bean sprouts in Taiwan, 131N on persimmon in U.S., 634N

C. boninense, on passion fruit in Florida, $786 \mathrm{~N}$

C. capsici on papaya in Florida, 1065N on passion fruit in Florida, $786 \mathrm{~N}$

C. cereale

in creeping bentgrass and annual bluegrass, $\beta$-tubulin 2 gene, thiophanate-methyl resistance and, 207 in turf grasses, azoxystrobin resistance, 751

C. coccodes, in potato, soil infestation, seed tuber and foliar inoculation, 905

C. gloeosporioides in pumpkin in Trinidad, $1062 \mathrm{~N}$ on ramie in China, $1508 \mathrm{~N}$

C. hanaui, on hairy crabgrass in China, $1510 \mathrm{~N}$

C. higginsianum, in Lepidium draba in

Europe, $1166 \mathrm{~N}$

C. magna, on papaya in Brazil, $1506 \mathrm{~N}$

C. sublineolum, on sorghum, anthracnose and, 589

on chili fruit, differential reactions to, 306

Colnago, P., 786N

Colyer, Patrick D., 1469

Conci, V. C., 915N

Coneflower. See Rudbeckia fulgida

Coniothyrium minitans

for control of Sclerotinia sclerotiorum in lettuce, Coniothyrium minitans for control of, 1118

Conklin, D. A., 115

Conn, K. L., 201

Connell, J. H., 1485

Continuous lighting, Podosphaera pannosa in hybrid roses and, 339

Convolvulus cneorum (silverbush), $131 \mathrm{~N}$, cover photo: January

Conyza canadensis (horseweed), Septoria erigerontis on, in Turkey, $918 \mathrm{~N}$

Cook, A. Z., 725

Cooke, L., $1063 \mathrm{~N}$

Copes, W. E., 891

Cordgrass. See Spartina alterniflora

Córdoba-Sellés, M. C., 1264N

Coriandrum sativum, Pythium ultimum on, in Italy, $1167 \mathrm{~N}$

Corky ringspot, on potato in North Dakota, $130 \mathrm{~N}$

Corn. See Zea mays

Cornyespora cassiicola, on balsam pear in China, $127 \mathrm{~N}$

Corylus avellana (hazelnut) Anisogramma anomala on, in New Jersey, $1265 \mathrm{~N}$

Fusarium lateritium on, in Italy, $484 \mathrm{~N}$

Corynespora cassiicola on cassava in China, $916 \mathrm{~N}$ on patchouli in China, $1508 \mathrm{~N}$

Costa, H., 1066N

Cotton. See Gossypium spp.

Couch grass. See Agropyron repens

Coutts, B. A., 1290

Cover crops for potato, soilborne diseases and, 1491 Pratylenchus brachyurus in, 1022

Cover photos

Ascochyta pisi on pea, June

Botrytis spp. on strawberry, March

Candidadus spp.

$\mathrm{Ca}$. Liberibacter psyllaurous on tomato, March 
$\mathrm{Ca}$. Liberibacter solanacearum on carrot, May

Ca.Phytoplasma asteris on showy rattlebox, October

Cercospora beticola on sugar beet,

November

citrus leprosis virus C, March

Enterobacter cloacae in onion, December

Fusarium oxysporum f. sp. palmarum in queen palm, January

Golovinomyces biocellatus on lemon balm in Hungary, September

malva vein clearing virus in hollyhock,

February

Meloidogyne spp. on tomato, August

Microbotryum violaceum on Silene latifolia, May

nematodes (plant-parasitic) attacking olive trees, February

Pantoea stewartii subsp. stewartii in corn, September

Papaya lethal yellowing virus in papaya, October

Phacidiopycnis washingtonensis in persimmon, June

Phytophthora palmivora and Veticillium dahlia on olive, November

phytoplasma infection of Rudbeckia sp., June

Plectosphaerella tabacinum on basil, April

Potato spindle tuber viroid in cape gooseberry, April

Potato virus $Y$ in potato, December

Puccinia coronata f. sp. avenae on oat, December

Rhizopus oryzae on sunflower, May

Sclerotinia homoeocarpa on grasses, February

Sclerotium rolfsii on silverbush, January

Stachybotrys chartarum on Tillandsia tenuifolia, September

Tobacco rattle virus on spinach, January

Turnip mosaic virus in mustard, November

Cox, K. D., 783N, 1283

CpCSV. See Chickpea chlorotic stunt virus

Crabapple. See Malus toringo

Crane, J. H., 1506N

Crane flower. See Strelitzia reginae

Creeping bentgrass. See Agrostis stolonifera

Cretazzo, E., $1507 \mathrm{~N}$

Cronartium ribicola, in gooseberry, comparative infectivity of asciospores and uredinisopores, 461

Crop rotation

potato soilborne diseases and, 1491

soilborn pathogens of cereals in irrigated cropping system and, 61

Crosby, W., 916N

Crosslin, J. M., 782N, 1506N, 1507N

Crotalaria spectabilis (showy rattlebox),

Candidatus Phytoplasma asteris on, in India,

$1265 \mathrm{~N}$, Cover photo: October

Crous, P. W., 278N, 1063N

Cruz, C. D., 820

Cruz, J., 1504N

Cruz, L., 1504N

CSD. See Citrus stubborn disease

Csösz, M., $1062 \mathrm{~N}$

Ctenanthe oppenheimiana, Rhizoctonia solania

on, in India, $126 \mathrm{~N}$

Cubeta, M. A., 455, 515

Cucumber. See Cucumis sativus

Cucumber mosaic virus (CMV) in Blephilia hirsuta in North America, 1070N

in Chinese peony in France, $790 \mathrm{~N}$

in lily in Argentina, 1188

in potato, cDNA microarray for detection of, 1248

in sweet cherry in China, $1378 \mathrm{~N}$

in Vigna marina in Taiwan, $1267 \mathrm{~N}$ in yardlong beans in Indonesia, $478 \mathrm{~N}$

Cucumis spp.

C. melo (melon)

Cucurbit chlorotic yellows virus in, in Taiwan, $1168 \mathrm{~N}$

Cucurbit yellow stunting disorder virus on, in China, $485 \mathrm{~N}$

Olpidium bornovanus on, pathogenicity and management, 163

Squash leaf curl virus in, in Palestinian Authority, 640N

transgenic for resistance to viruses, 1341

C. sativus (cucumber)

Cucurbit chlorotic yellows virus in, in Taiwan, $1168 \mathrm{~N}$

Fusarium solani on, in China, 1377N

Glomerella magna in, in Taiwan, 787N

Phytophthora capsici in, temperature, concentration, age, algaecides and zoospore infectivity, 54

Phytophthora capsici in, temperature, humidity, wounding and, 1417

Squash leaf curl virus in, in Palestinian Authority, 640N

Zucchini yellow mosaic virus in, in Ivory Coast, $1378 \mathrm{~N}$

Cucurbit chlorotic yellows virus (CCYV), in cucurbits in Taiwan, $1168 \mathrm{~N}$

Cucurbit yellow stunting disorder virus

(CYSDV), on melon in China, $485 \mathrm{~N}$

Cucurbita spp.

C. lanatus (watermelon), Meloidogyne

incognita in, grafting root stock for

management of, 1195

C. moschata (pumpkin)

Colletotrichum gloeosporioides in, in Trinidad, $1062 \mathrm{~N}$

Cucurbit chlorotic yellows virus in, in Taiwan, $1168 \mathrm{~N}$

C. pepo (zucchini)

Papaya ringspot virus in, in Poland, $633 \mathrm{~N}$

Squash leaf curl virus in, in Palestinian Authority, 640N

Zucchini yellow mosaic virus in, in Ivory Coast, $1378 \mathrm{~N}$

Cui, G. F., 280N

Cui, L., 881

Cui, X. P., 1508N

Culbreath, A. K., 676, 683, 898

Cupressus funebris (Chinese weeping cypress), Neofusicoccum parvum in, in China, 641N

Curly top disease, in tomato, curtoviruses and, 99

Currant. See Ribes spp.

Curtoviruses, in tomato, curly top disease and, 99

Curvetto, N. R., 1188

Curvularia lunata

resistance to in sorghum, in mini-core

germplasm collection, 439

on strawberry in India, $477 \mathrm{~N}$

Cuscuta spp. and transmission of Grapevine

leafroll-associated virus-7

C. europea, 471

C. reflexa, 471

CVd-V. See Citrus viroid V; Citrus viroid V

Cylindrocladium spp.

C. parasiticum, on soybean in China, $485 \mathrm{~N}$

C. pauciramosum, on dwarf willow myrtle in Italy, $274 \mathrm{~N}$

Cymbopogon spp., essential oils of, Ralstonia

solanacearum in ginger and, 521

Cynara cardunculus (artichoke)

Verticillium dahliae in, diversity and host range, in Spain, 396

Verticillium wilt as threat to, 1176

Cypress, weeping. See Cupressus funebris

CYSDV. See Cucurbit yellow stunting disorder virus

Cyst nematode. See Heterodera filipjevi
Cytorhabdovirus sp., in soybean in South Africa, 1348

Daane, K. M., 827

Dagostin, S., 575

Dal Prà, M., 1070N

Dalton, D. T., 461

Damayanti, T. A., $478 \mathrm{~N}$

Damping off, in peanut, evaluation of treatments for control of, 445

Damsteegt, V. D., 528

Das, A. K., 375N

Daucus carota (carrot)

Alternaria dauci on, aggressiveness and fungicide sensitivity, 405

Alternaria radicina on seed from New Zealand, $1168 \mathrm{~N}$

Candidatus Liberibacter solanacearum on, in Europe, psyllids and, 639N, Cover photo: May

Erysiphe heraclei on, in Mexico, 483N

Spiroplasma citri in, in Europe, $1264 \mathrm{~N}$

Xanthomonas hortorum pv. carotae on, in

Mauritius, $1069 \mathrm{~N}$

Daugherty, C., 134N

David, N., 130N, 1506N

Davino, M., $1172 \mathrm{~N}$

Davino, S., $1172 \mathrm{~N}$

Davis, R. M., 276N, 690, 986

Davitt, C. M., 782N

Davolio Marani, O., 372N

de a Cerda, K., 751

de Araújo Filho, J. V., 790N

De Bac, G., 482N

De Boer, S., 1384

De Cal, A., 1048

De Cara, M., 277N

de la Cerda, J., 207, 277N

de Lapeyre de Bellaire, L., 648

De S. Carneiro, J. E., 361

Deahl, K. L., 1063N

Debaeke, P., 1398

Dechamp-Guillaume, G., 1398

Decraemer, W., $782 \mathrm{~N}$

Degirmenci, K., 641N, 1261N

del Mar Jiménez-Gasco, M., 1176

Delmiglio, C., 479N

Dendrobium spp., Impatiens necrotic spot virus in, in China, $915 \mathrm{~N}$

Dendrocalamus giganteus, Clonostachys rhizophaga on, in Mozambique, 372N

Deng, M., 485N

Deng, Q., 485N

Deng, T.-C., $1267 \mathrm{~N}$

Deng, W.-L., 1065N

Deoxynivalenol, in flour and bran of spring wheat lines with different levels of Fusarium head blight resistance, 335

Dernoeden, P. H., 596

Des Jardin, E. A., 31

Desbiez, C., 1378N

Desjardin, D. E., 1374N

Desjardins, M., 377N

Detweiler, A. R., 922N

Diaphorina citri (Asian citrus psyllid) and

Candidatus Liberibacter asiaticus in Belize, $781 \mathrm{~N}$

lack of evidence of transmission through seeds of affected fruit, 1195 on Murraya spp., 528

Diaporthe phaseolorum, on soybean in Iowa, 167

Dias, A., $1170 \mathrm{~N}$

Dias, A. P., 796

Diatrypaceae spp., on grapevines in California, pathogenicity of, 867

Diaz, J., 1266N

Diaz, M. G. Q., 311

Díaz-Pendón, J. A., 179

Dicenta, F., 275N

Dickeya spp. 
on banana in China, $640 \mathrm{~N}$

D. dadantii, in potato in Zimbabwe, $1263 \mathrm{~N}$

on sweetpotato in China, $1503 \mathrm{~N}$

Dicklow, M. B., 484N

Didymella sp., on milky bellflower in Italy, $638 \mathrm{~N}$

Digitaria sanguinalis (hairy crabgrass),

Colletotrichum hanaui on, in China, $1510 \mathrm{~N}$

Dillard, H. R., 213, 1461

Dilmaghani, A., $791 \mathrm{~N}$

Dimbi, S., 1067N

Ding, Y.-M., $915 \mathrm{~N}$

Dinolfo, M. I., 783N

Dioscorea nipponica (throughhill yam),

Rhizoctonia solani on, in China, $915 \mathrm{~N}$

Diospyros kaki (persimmon)

Alternaria alternata in, in Turkey, 1069N

Colletotrichum acutatum on, in U.S., 634N

leaf spot on, Mycosphaerella nawae and, $374 \mathrm{~N}$

Phacidiopycnis washingtonensis in, in Italy, $788 \mathrm{~N}$, Cover photo: June

Diplodia spp.

D. corticola

on coast live oak in California, $1510 \mathrm{~N}$ on grapevine and canyon live oak in California, $785 \mathrm{~N}$

D. scrobiculata, on strawberry tree in Italy, $919 \mathrm{~N}$

Disinfectants

for Fusarium oxysporum f. sp. vasinfectum on cottonseed, dry heat and hot water treatments as, 1469

for Tobacco mosaic virus-contaminated tools, 542

Dithofencarb, Botrytis cinerea and, multiple resistance and, 551

Ditmore, M., 589

Dixon, L. J., 279N, 293, 1169N

Dixon, M., $1261 \mathrm{~N}$

Djekiæ, I., 703

Dodder transmission, by Cuscata spp.,

Grapevine leafroll-associated virus-7 and, 471

Dong, H., 1441

Dong, J. H., 132N

Dong, M. M., 640N

Dong, S., 881

Dong, Y. -F., 130N

Dorrance, A. E., 125N, 265, 820

Dottin, M., 1264N

Douglas, J. M., 481N

Douglas, S. M., 279N

Dracaena reflexa, Burkholderia gladioli in, $781 \mathrm{~N}$

Draeculacephala minerva (green sharpshooter) and Xylella fastidiosa, diseases in California, 827

Druffel, K. L., $1261 \mathrm{~N}$

Du, X. F., 1378N

du Toit, L. J., 236, 1425

Duan, Y. B., 271N

Duarte, H. S. S., 1378N

Dufault, N. S., 1336

Dung, J. K. S., 1255

Dunn, A. R., 1461

Duran-Vila, N., $129 \mathrm{~N}$

Durham, T. C., $487 \mathrm{~N}$

Durrin, J. S., 972

Durum wheat. See Triticum turgidum

Dwarf sweet plum. See Prunus aitianli

Dykema, N. M., 922N

Early leaf spot, Cercospora arachidicola in peanut, night spraying of fungicides and, 676, 683

Eastern filbert blight (EFB), Anisogramma anomala on European hazelnut in New Jersey, $1265 \mathrm{~N}$

Eastwell, K. C., 782N, 1067N

Eckhoff, J., 1100

Ecological and evolutionary processes, diseases in natural plant populations, communities, and ecosystems, 492

Edgeworthia papyrifera (oriental paperbush), $917 \mathrm{~N}$

EF-1 $\alpha$, Fusarium oxysporum $\mathrm{f}$. sp. palmarum in queen and Mexican fan palms in Florida and, 31

Egel, D., 484N

Eisenback, J. D., 781N

Elibox, W., 1243

Elliott, M. L., 31, 1163N

Ellis, M. L., $125 \mathrm{~N}$

Elm yellows (EY) phytoplasma, in American

elm and insects, real-time PCR for, 1355

Eloy, M., 1504N

Emerson, M. J., $1168 \mathrm{~N}$

Endangered species, seabeach sandwort,

Uromyces acuminatus on, $279 \mathrm{~N}$

Engel, E. A., 633N, 1067N

Engelbrecht, M., 373N

English walnut. See Juglans regia

Enterobacter cloacae, on onion postharvest curing parameters and, 1425 , Cover photo: December and resistance, 236

Epichloë bromicola, on couch grass in Poland, $1372 \mathrm{~N}$

Epifani, F., 1509N

Eremophila spp., Fusarium oxysporum on, in Italy, $1509 \mathrm{~N}$

Eriobotrya japonica (loquat), Alternaria sp. on, in Taiwan, $481 \mathrm{~N}$

Eroglu, S., 1374N

Erper, I., 918N

Errata, 1366

Ertan, D., 923N

Erwinia spp.

E. amylovora, HrpNEa protein of, for Pectobacterium carotovora subsp. carotovora resistance in Chinese cabbage, 1441

E. carotovora, on potato in Nepal, $382 \mathrm{~N}$

Erysiphe heraclei, on carrot in Mexico, 483N

Escobar, P. F., 1067N

Esgar, R. W., 1111

Eskalen, A., 1510N

Esker, P. D., 796

Essential oils, Ralstonia solanacearum in ginger and, 521

Etarock, B. F., 638N

Eucalyptus spp. Chrysoporthe cubensis in, in China, 1143 essential oils of, Ralstonia solanacearum in ginger and, 521

Eupatorium purpureum L. (joe-pye weed), Tobacco ringspot virus in, in Mississippi, $126 \mathrm{~N}$

Euphorbia pulcherrima (poinsettia), 791N

European beech. See Fagus sylvatica

European hazelnut. See Corylus avellana

European plum line pattern, Apple mosaic virus in plum in Turkey, $641 \mathrm{~N}$

Evans, R. G., 1100

Everts, K. L., 92

Evett, S. R., 766

Exadaktylou, E., 1503N

EY phytoplasma. See Elm yellows (EY) phytoplasma

Facchinetti, C., 1188

Faedda, R., 1372N, 1374N

Fagus sylvatica (European beech), Phytophthora spp. on, 1009

Fairweather, M. L., 115

Fajolu, O. L., 1505N

False smut. See Ustilaginoidea virens

Fan, X. -D., 130N

Fang, B. P., 1503N

Fang, W., 482N

Farnham, M. W., 132N

Farnsworth, J. L., 425
Faure, C., 477N

FDS. See Fern distortion syndrome

Felgueiras, M., 1170N

Fellers, J. P., 1125

Feng, C. T., $1164 \mathrm{~N}$

Fern distortion syndrome (FDS), in leatherleaf fern in Costa Rica, 940

Fernandes, P. M. B., 1509N

Fernández-Muñoz, R., 179

Fernández-Pavía, S. P., 483N

Ferrándiz, J. C., 1264N

Ferreira, J. J., 885

Ferreira, M. F., $1506 \mathrm{~N}$

Ferrin, D. M., 274N

Ficsor, A., 1062N

Ficus carica (fig), Fig mosaic virus in, comparison of isolates, 1448

Fidanza, M. A., 1379N

Fig mosaic virus (FMV), in fig, comparison of isolates, 1448

Figmarigold. See Lampranthus spp.

Fir, California red. See Abies magnifica

Fire bush. See Streptosolen jamesonii

Fisher, A. J., 174

Fisher, T. W., 639N

Fletcher, J., 75

Flooding, for Fusarium oxysporum f. sp.

lactucae in lettuce, 1323

Floreancig, V., 133N

Flores-Zamora, G. L., 388

Flory, S. L., 807

Flowering ginger. See Alpinia purpurata

FMV. See Fig mosaic virus

Focus, 3, 147, 283, 387, 491, 647, 795, 927 $1075,1175,1271,1383$

Fonseca, M. E. N., 179, 781N

Font, M. I., 1264N

Formolo, T., 575

Förster, H., 1485

Fortner, J., $1168 \mathrm{~N}$

Foster, J. M., 24, 697

Fourie, P. H., $1063 \mathrm{~N}$

Fragaria $\times$ ananassa (strawberry)

Curvularia lunata on, in India, $477 \mathrm{~N}$ gray mold from Botrytis spp. on, 284, Cover photo: March

Franceschini, A., 919N, 1068N

Franceschini, S., 272N

Fraxinus excelsior (common ash), Chalara

fraxinea on, in Italy, 133N

Frayssinet, S., 488N

Freeman, S., $1506 \mathrm{~N}$

French-Monar, R. D., 481N

Friesen, T. L., 480N

Friskop, A., $273 \mathrm{~N}$

Fry, W. E., 1461

Fu, B., $1505 \mathrm{~N}$

Fuchsia $\times$ hybrida, Phoma multirostrata on, in

Italy, 382N

Fuentes, S., 510

Fukuda, S. K., 641N

Fungicides

for Botrytis cinerea multiple resistance to, 551 resistance to, on raspberry, $486 \mathrm{~N}$ on table grapes and, 250

for Cercospora beticola on sugar beet, 1272 , Cover photo: November

for Colletotrichum cereale resistance to, $\beta$-tubulin 2 gene and, 207 resistance to in turf grasses, 751

on corn with simulated hail damage, 83

demethylation inhibitor, Monilinia fructicola on in New Jersey and, $126 \mathrm{~N}$

Gibberella zeae in wheat, resistance to, 1137 mancozeb, 1076

MBI-D, Pyricularia oryzae resistance after discontinuance of, 329

for Monilinia fructicola on peach quinone outside inhibitor fungicide, 1000 reduced sensitivity to, 737,1366 
$\beta$-tubulin E198A allele and fungicide resistance, $1511 \mathrm{~N}$

for Phytophthora spp.

P. capsici, 697, 1461

P. nicotianae, 1355

P. sojae, 873

strobilurin, processing sweet corn and, 213

for Venturia inaequalis in apple and

crabapple, resistance to, 744

Furiki, M., 812

Furrow irrigation, Ustilaginoidea virens in rice and, 563

Fusarium spp.

$F$. andiyazi, on rice in Italy, $1070 \mathrm{~N}$

F. culmorum, in cereals in irrigated cropping system, and tillage, residue management, and crop rotation, 61

F. foetens, in Hiemalis begonias in Canada, $1261 \mathrm{~N}$

$F$. graminearum, deoxynivalenol in flour and bran of spring wheat lines with different levels of resistance to, 335

F. lateritium, on hazelnut in Italy, $484 \mathrm{~N}$

F. oxysporum

on banana in India, 1379N on basil in Portugal, 1170N on cottonseed, dry heat and hot water treatments for disinfection, 1469 on Eremophila spp. in Italy, 1509N on lavender in Saudi Arabia, 1163N on lettuce: PCR-based detection assay for, 860; soil solarization and flooding for, 1323; temperature and severity of wilt, 13

on paper flower in Italy, $483 \mathrm{~N}$ on tomato in Mexico, $1376 \mathrm{~N}$ on Washingtonia robusta and Syagrus romanzoffiana in Florida, 31, Cover photo: January on watermelon, race 3 and, 92

$F$. proliferatum on garlic bulbs in Spain, 277N on oat in Argentina, 783N

$F$. pseudograminearum, on cereals in irrigated cropping system, and tillage, residue management, and crop rotation, 61

F. redolens, on soybean in Minnesota, $1069 \mathrm{~N}$

F. semitectum, on Persian/English walnut, $791 \mathrm{~N}$

F. solani on Angelica acutiloba in Taiwan, 1164N on grafted cucumber in China, 1377N on pepper in Trinidad, $1375 \mathrm{~N}$

F. tucumaniae, on soybean, sexual reproduction of, 1411

$F$. virguliforme, on soybean in Michigan, $1164 \mathrm{~N}$

fuzzy pedicel on banana and, 621

resistance to in sorghum, in mini-core germplasm collection, 439

Fuzzy pedicel, on banana, 621

Gadoury, D. M., 339, 1105

Gagnevin, L., 993

Gai, J. Y., 351

Galdames, R., $1266 \mathrm{~N}$

Galizio, R., 783N

Galli, M., 134N

Gallup, C. A., 455, 557

Galván, G. A., 786N

Gamarra, H. A., 510

Gambley, C. F., 486N

Gan, B. C., 1508N

Gao, F., 378N

Gao, J., $915 \mathrm{~N}$

Gao, W., $127 \mathrm{~N}$

Gao, X., 485N

Gao, Z. H., 918N

Garbanzo. See Cicer arietinum

García-Ibarra, A., 275N
García-Jiménez, J., 278N, 374N, 534

García-Pedrajas, M. D., 380N

Garczynski, S. F., 639N

Garg, H., 1041

Garibaldi, A., 129N, 130N, 380N, 382N, 638N, $788 \mathrm{~N}, 917 \mathrm{~N}, 1066 \mathrm{~N}, 1071 \mathrm{~N}, 1076,1167 \mathrm{~N}$

$1171 \mathrm{~N}, 1504 \mathrm{~N}$

Garlic. See Allium sativum

Gavrielova, S., 272N

Gawande, S. J., 1066N

Gazel, M., 1448

Geiser, D. M., 31

Gent, D. H., 425, 1305

Geotrichum citri-aurantii, on key lime in Mexico, $488 \mathrm{~N}$

Gerbera jamesonii, Golovinomyces cichoracearum on, in Italy, $130 \mathrm{~N}$

GFkV. See Grapevine fleck virus

Giant blazing star. See Mentzelia laevicaulis

Giayetto, A. L., $488 \mathrm{~N}$

Gibberella zeae, in wheat. See also Fusarium graminearum

carbendazim resistance, 1137

long-distance dispersal from corn residue, 1151

Gilardi, G., 382N, 1071N, 1167N, 1504N

Gilbertson, R. L., 99, 482N

Ginger. See Zingiber officinale

Giovannini, O., 575

Giraldez, R., 885

Giselrød, H. R., 339

Gislerød, H. R., 1105

Gispert, C., 717

Glass, M. E., 1379N

Glawe, D. W., $132 \mathrm{~N}$

Globodera spp.

G. pallida (potato cyst nematode), weed

hosts of in Idaho, $918 \mathrm{~N}$

G. rostochiensis (golden potato cyst nematode)

on potato in British Columbia, 1367 on potato in Quebec, $1510 \mathrm{~N}$ multiplex real-time PCR assay for, 959

Glomerella spp.

on cucurbits in Taiwan, $787 \mathrm{~N}$

on passion fruit in Florida, 786N

Glover, R., 510

GLRaV. See Grapevine leafroll-associated

viruses

Glycine max (soybean)

Alfalfa mosaic virus in, in Tennessee, $1505 \mathrm{~N}$

Bean pod mottle virus in, insect-resistance and, 265

Belonolaimus longicaudatus on, in Delaware, $133 \mathrm{~N}$

Cylindrocladium parasiticum on, in China, $485 \mathrm{~N}$

Cytorhabdovirus sp. in, in South Africa, 1348

Fusarium spp. on

$F$. virguliforme, in Michigan, $1164 \mathrm{~N}$

$F$. redolens, in Minnesota, $1069 \mathrm{~N}$

$F$. tucumaniae, sexual reproduction of, 1411

Macrophomina phaseolina in, conidia production by isolates in culture, 1088

Phakopsora pachyrhizi on culturing in detached leaves, 1453 rainfall runoff and, 1336 understanding risk in different regions of world, 796

Phialophora gregata f. sp. sojae on, effect of monoculture on aggressiveness of, 69

Phomopsis spp. on, aggressiveness of, 1026

Phytophthora spp. on

$P$. sansomeana, in China, $378 \mathrm{~N}$

P. sojae: calcium for reduction of, 812 ; in China, 873; chloride and ammonium salts and, 758; races and virulence of, 87; resistance of commercial cultivars, 361
Septoria glycines on, in Ohio, 820

soybean cyst nematode in, dry bean growth and, 1299

soybean mosaic virus strains on, in southern

China, 351

stem canker of in Iowa, 167

Thielaviopsis basicola on, in Arkansas, $1168 \mathrm{~N}$

Gmitter, F. G., 1200

Golden potato cyst nematode. See Globodera rostochiensis

Golovinomyces spp.

G. biocellatus

on lemon balm in Hungary, 1169N,

Cover photo: September

on peppermint in California, 276N

on spearmint in Italy, $1171 \mathrm{~N}$

G. cichoracearum, on Gerbera jamesonii in Italy, $130 \mathrm{~N}$

Gómez-Cabrera, R., 380N

González, N., 277N

González, P. H., 786N

González-Franco, A. C., 1262N

Gooseberry. See Physalis peruviana (cape gooseberry); Ribes nigrum

Gopal Reddy, V., 439

Gordon, T. R., 13

Górzyñska, K., 1372N

Goss's bacterial wilt, Clavibacter michiganensis subsp. nebraskensis in corn in Minnesota, $1064 \mathrm{~N}$

Gossypium spp. (cotton)

Fusarium oxysporum f. sp. vasinfectum on, dry heat and hot water treatments for disinfection, 1469

Rhizoctonia spp. in, in Greece, 1314

Goswami, R. S., 789N, 1299

Gottwald, T. R., 725

Gourd. See Momordica charantia

Gouziotis, A., 1314

Goyeau, H., 1068N

Grafting, Sclerotium rolfsii and Meloidogyne spp. on tomato, disease management and,

1015, Cover photo: August

Graham, J. H., 725

Grain mold, resistance to in sorghum, in minicore germplasm collection, 439

Gram. See Cicer arietinum

Granke, L. L., 54, 843, 1417

Grant, J., 1167N

Grapefruit, Xanthomonas citri subsp. citri in, in Florida, wind speed and dispersal downwind from infected trees, 725

Grapevine. See Vitis vinifera

Grapevine fleck virus (GFkV), in grapevine in Washington, 784N

Grapevine leafroll-associated viruses (GLRaVs)

GLRaV-5

in grapevine in Chile, $1067 \mathrm{~N}$

in grapevine in Spain, 1507N

GLRaV-7, on Tetragonia expansa, 471

on grapevine in China, $130 \mathrm{~N}$

Grapevine Syrah virus-1 (GSyV-1), in grapevine

in Chile, $633 \mathrm{~N}$

in Washington, $787 \mathrm{~N}$

Grau, C. R., 69

Graves, W. L., 293

Gray, M. E., 480N

Gray, S., 1384

Green, S. K., 637N

Green sharpshooter. See Draeculacephala minerva

Greening disease of citrus, Candidatus spp. in in South Africa, 244

Gregory, N. F., 1169N

Griffin, R. L., 781N

Griffin, T. S., 1491

Grigoras, I., 642N

Groenewald, J. Z., 278N 
Gronenborn, B., 642N

Gross, Dennis C., 143

Groves, R. L., 827

Grybauskas, A. P., 596

Gryzenhout, M., 1143

Gu, P., 977

Gu, X. C., $1262 \mathrm{~N}$

Guan, M., 485N

Guarnaccia, V., 125N, 131N, 483N, 486N, $1509 \mathrm{~N}$

Gubler, W. D., 717, 785N, 867, 1167N, 1267N, 1476

Gudmestad, N. C., 130N, 659, 905, 1272, $1506 \mathrm{~N}$

Guilmarães, I. M., 278N

Gullino, M. L., 129N, 130N, 380N, 382N $638 \mathrm{~N}, 788 \mathrm{~N}, 917 \mathrm{~N}, 1066 \mathrm{~N}, 1071 \mathrm{~N}, 1076$, $1167 \mathrm{~N}, 1171 \mathrm{~N}, 1504 \mathrm{~N}$

Gulya, T., 273N

Guo, K., 376N

Guo, L. Y., 478N

Guo, Y.-L., 1377N

Gupta, V. K., 477N

Gurung, S., 229

Gymnosporangium yamadae, on Juniperus chinensis and apple in North America, 1169N

Hail damage, Quinone outside inhibitor (QoI) foliar fungicides on corn with, 83

Hairy crabgrass. See Digitaria sanguinalis

Hajimorad, M. R., 1505N

Halbert, S. E., 1200

Hall, B. H., 486N

Halleen, F., 1063N

Hamilton, J. P., 311

Hamlin, L. L., $1507 \mathrm{~N}$

Hammond, R. B., 265

Hampton, J. G., 1168N

Hamza, A. A., 993, 1264N

Han, H., 922N

Handoo, Z. A., 133N

Hanna, J. W., 784N, 1503N

Hanson, L. E., 504

Hanson, S. L., 1100

Hao, B., 221

Hao, W., 274N

Hao, Y. Wu, X., 977

Harman, G. E., 928

Harmon, P. F., 966

Harper, S. J., 479N

Harrington, T. C., 115

Harrison, N. A., 31

Hartman, G. L., 361, 477N, 1035, 1088, 1543

Hartung, J. S., 1200

Hashim-Buckey, J., 250

Hassani-Mehraban, A., 1070N

Hassell, R. L., 1195

Hataya, T., 1248

Haudenshield, J. S., 477N

Haugen, L. M., 277N

Hauptman, T., 133N

Hausbeck, M. K., 24, 54, 697, 843, 1417

Hay, F. S., 1305

Hayes, A. J., 542

Hazelnut. See Corylus avellana

He, H. Q., 1172N

He, Z., 201

He, Z. H., 45

Head blight, Fusarium proliferatum on oat in Argentina, 783N

Helianthus annuus (sunflower) Phoma macdonaldii on, 1398

Puccinia helianthi on, in Illinois, 273N

Rhizoctonia solani on, in India, 488N

Rhizopus oryzae on, in New Mexico, 638N, Cover photo: May

Helleborus spp., Helleborus net necrosis virus in, in New Zealand, 479N

Henne, D. C., 659

Henry, B. R., 1111

Herath, P., 1355
Herbaspirillum rubrisubalbicans, on sugarcane in China, mottled stripe disease and, 379N

Hermoso de Mendoza, A., 1264N

Hernandez, C., 917N

Hernandez-Gonzalez, J., 1266N

Hernández-Huerta, J., 1262N

Hernández-Montiel, L. G., 488N

Hernández-Verdugo, S., 1376N

Hernandez-Zepeda, C., 924N

Herrero, M. L., 339, 1105

Heterobasidion spp., in southern Rocky

Mountains and adjoining states, 115

Heterodera spp.

$H$. filipjevi (cereal cyst nematode), on wheat in China, $1262 \mathrm{~N}, 1505 \mathrm{~N}$

$H$. glycines (soybean cyst nematode), on soybean, 1299

Hickory. See Carya cordiformis

Hidcote. See Hypericum patulum

Hiemalis begonias, Fusarium foetens in, in Canada, $1261 \mathrm{~N}$

Hilber-Bodmer, M., 643N

Hill, C. B., 1088

Hines, R. A., 477N

Hirsch, R. L., 381N

Hita, I., 635N, 1507N

Ho, W. C., $1164 \mathrm{~N}$

Hoke, S., 484N

Holcomb, G. E., 272N

Holguin-Peña, J., 1266N

Holguín-Peña, R. J., 488N

Hollyhock. See Alcea rosea

Holub, V., 272N

Honckenya peploides (seabeach sandwort), Uromyces acuminatus on, $279 \mathrm{~N}$

Honeycutt, C. W., 1491

Hong, C., 39

Hong, C. X., 274N, 1361

Hong, J. P., 1372N

Hong, N., $1071 \mathrm{~N}$

Hoover, G. A., 1355

Hop. See Humulus lupulus

Hordeum vulgare (barley), Pyrenophora teres in in Hungary, $1062 \mathrm{~N}$ in North Dakota, $480 \mathrm{~N}$

Horgan, B. P., 1165N

Horseweed. See Conyza canadensis

Hostachy, B., 1069N, 1373N

Hou, X. S., 1505N

Howard, R. J., 377N

Howell, W. E., 1067N

HrpNEa protein of Erwinia amylovora, for Pectobacterium carotovora subsp. carotovora resistance in Chinese cabbage, 1441

Hsiang, T., 277N, 373N, 1231

Hsiao, W. W., 487N

$\mathrm{Hu}$, J., 39, 196

Hu, J. S., 641N, 921N, 1508N

$\mathrm{Hu}, \mathrm{M} . \mathrm{X} ., 271 \mathrm{~N}$

Hu, X., 221

Huang, C.-H., 920N, 1263N

Huang, G.-X., 916N, 919N

Huang, J., 1231

Huang, L. F., 1503N

Huang, L.-H., $1168 \mathrm{~N}$

Huang, Q., 274N

Huang, T.-C., $1065 \mathrm{~N}$

Huang, W.-C., $1267 \mathrm{~N}$

Huang, Z., 379N

Huanglongbing (HLB) and Candidatus

Liberibacter asiaticus

lack of evidence of transmission through seeds of affected fruit, 1195

in Murraya spp., 528

in satkara in India, $375 \mathrm{~N}$

in sweet orange, in Ethiopia, $482 \mathrm{~N}$

in sweet orange, Mexican lime, and Asian citrus psyllid, in Belize, $781 \mathrm{~N}$

Hudler, G. W., 1009

Huerta-Espino, J., 413

Hughes, M., 634N
Hughes, M. E., 775

Hughes, T. J., 69

Hullé, M., 477N

Hummer, K. E., 461

Humulus lupulus (hop), Pseudoperonospora humuli on, forecasting and management of, 425

Hung, T. H., $128 \mathrm{~N}$

Hunter, D. M., 634N

Hurtado, J., 1476

Husein, E. Y., 640N

Hwang, Y. J., 280N

Hyakumachi, M., 275N

Hyder, N., 919N

Hydrangea macrophylla, Myrothecium roridum on, in U.S., $1266 \mathrm{~N}$

Hylocereus undatus (pitahaya), Bipolaris

cactivora on, in Florida, 1506N

Hymenocallis littoralis (spiderlily), Impatiens necrotic spot virus in, in China, $484 \mathrm{~N}$

Hypericum patulum (hidcote), Pestalotiopsis microspora in, in Japan, 1064N

Iacono, G., $1172 \mathrm{~N}$

Idiarte, H. González, 786N

Idris, A. M., $376 \mathrm{~N}$

Iglesias, C., $277 \mathrm{~N}$

Impatiens necrotic spot virus (INSV)

in orchids in China, $915 \mathrm{~N}$

in potato in Washington, $1507 \mathrm{~N}$

in spiderlily in China, 484N

Ingram, D. M., 126N

Ink disease, Phytophthora pseudosyringae in chestnut in Italy, 1068N

Inomoto, M. M., 1022

INSV. See Impatiens necrotic spot virus

International Maize and Wheat Improvement Center (CIMMYT), 413

Ipomoea batatas (sweetpotato) Dickeya sp. in, in China, $1503 \mathrm{~N}$

Sweet potato chlorotic stunt virus in, Bemisia tabaci and, 510

Iprodione, Sclerotinia homoeocarpa in creeping bentgrass, 596

Iresine viroid 1 (IrVd-1), in Celosia plumosa in Netherlands, $920 \mathrm{~N}$

Irey, M., 781N

Iris yellow spot virus (IYSV)

in garlic in India, 1066N

in leek in Sri Lanka, 1070N

in onion

in Hawaii, $1508 \mathrm{~N}$

in Mauritius, $1373 \mathrm{~N}$

in Uruguay, $786 \mathrm{~N}$

Irrigation

soilborne pathogens of cereals, and tillage, residue management, crop rotation, 61

Ustilaginoidea virens in rice and, 563

IrVd-1. See Iresine viroid 1

Isakeit, T., 792N, 924N

Isard, S. A., 1336

Ishihara, M., 358

Ishimaru, C. A., 1064N

Ito, M., 335

Ivanoviæ, M., 486N

Ivey, M. L. L., 109

Ivors, K. L., 515

Ixora coccinea, Pseudocercospora ixoricola on, in Brazil, $278 \mathrm{~N}$

IYSV. See Iris yellow spot virus

Jacobs, K., 666

Jacobsen, B. J., 372N

Jadão, A. S., 789N, 1066N

Jamous, R. M., 640N

Jan, F.-J., 920N, 1263N

Jansen, C. C. C., $791 \mathrm{~N}, 920 \mathrm{~N}$

Japanese apple rust, on Juniperus chinensis and apple in North America, 1169N

Japanese stiltgrass. See Microstegium vimineum

Jaroszewska, B. Hasiów-, 633N 
Jaspers, M. V., 1168N

Jayanty, S. S., 1329

Jelkmann, W., 471

Jensen, B., 432

Jensen, B. D., 298

Jensen, T., 478N

Jeong, I. H., 271N, 790N

Ji, P., 1379N

Jia, Z., 1441

Jiang, D., 1231

Jiang, H., 1508N, 1510N

Jiang, J., 1137

Jiang, J.-H., 1166N

Jijakli, M. H., 648

Jiménez-Díaz, R. M., 148, 396, 1176

Jiménez-Gasco, M. M., 396

Jin, Y., 413

Johnson, C. S., 1361

Johnson, D. A., 18, 921N, 1255

Johnson, K. B., 581

Jones, D. C., 766, 771

Jones, L., 378N, 487N

Jones, M. G. K., 1264N

Jones, R. A. C., 563, 1290

Jones, R. W., 1063N

Joos, D. K., 1111

Jordá, C., 1264N

Jordahl, J., 273N

Jordão, H., 1170N

Joshi, V., 277N

Joubert, J., 373N

Jouen, E., 993, 1069N, 1264N

Joviæ, J., 703

Juglans spp.

J. cinerea (butternut), Sirococcus clavigignenti-juglandacearum on, molecular diagnostic assay for, 952

$J$. regia (English walnut)

Fusarium semitectum on, in Italy, 791N

Neofusicoccum mediterraneum on, in California, $1267 \mathrm{~N}$

Jung, G., 186

Juniperus chinensis, Gymnosporangium yamadae on, in North America, 1169N Jurc, D., 133N

Jurick II, W. M., 258

Juzwik, J., 277N

Kalischuk, M. L., 377N

Kalogeropoulou, P., 1314

Kaminski, J. E., 186

Kang, S., 638N

Kang, Y. B., 271N

Kang, Z., 221

Kanzaki, N., 358

Karaoglanidis, G. S., 1314

Karasev, A., 1384

Karasev, A. V., 972, 1262N

Károlyi-Cséplö, M., 1062N

Kasdorf, G. G. F., 1348

Kassai-Jáger, E., 1169N

Kato, M., 275N

Kaur, R., 636N

Kaviani, M., 634N

Kaya, K., 1448

Kehoe, M. A., 1290

Keinath, A. P., 132N

Keith, L., 128N

Keller, B., 413

Keller, K. E., 1132

Keller, M. D., 1151

Kemerait, R. C., 898

Kemmitt, G. M., 1076

Kennedy, R., 851

Kenyon, L., 378N, 637N, 923N

Kerns, J. P., $1165 \mathrm{~N}$

Key lime. See Citrus aurantifolia

Khan, M. F. R., 1272

Khar, A., 1066N

Kidney bean. See Phaseolus vulgaris

Kidney bean little leaf disease, 16SrII group phytoplasma and, in China, 132N

Kim, M.-S., 784N, 1266N, 1503N

Kim, O.-K., 1225

Kim, S. B., $1372 \mathrm{~N}$

Kim, S. H., 638N

Kim, W. G., 1164N

Kim, Y. K., 604

Kiss, L., 1169N

Kitajima, E. W., 283

Kiwi. See Actinidia deliciosa

Klebsiella sp., on pineapple in Brazil, 1509N

Kleczewski, N. M., 807

Kloeckera sp., on pineapple in Brazil, 1509N

Kloepper, J. W., 940

Klopfenstein, N. B., 784N, 1503N

Knierim, D., 923N

Knott, C., 636N

Ko, Y., $481 \mathrm{~N}$

Koba, A., 329

Koch, P. L., 1165N

Koike, S. T., 13, 125N, 131N, 640N, 1375N

Kolmer, J., 420

Kolmer, J. A., 628, 775

Koné, D., 1378N, 1379N

Kong, C. S., $1373 \mathrm{~N}$

Koohi-Habibi, M., 127N

Korres, A. M. N., 1509N

Korsten, L., 244

Koski, A., 919N

Kouadio, Y. J., 1379N

Kousik, C. S., 1195

Koutita, O., 1314

Kratky, B. A., 521

Kraus, J., 1132

Krid, S., 636N

Krnjajiæ, S., 703

Krstiæ, B., 703

Kubelková, D., 1071N

Kubo, K. S., 283

Kudzu. See Pueraria montana var. lobata

Kuhlmann, M., 528

Kumar, A., 375N

Kumar, R., 126N

Kumar, S., $1265 \mathrm{~N}$

Kumari, S. G., 1068N

Kuo, F.-Y., 920N

Kurbetli, I., $1261 \mathrm{~N}$

Kurt, S., 1069N

Kyle, D., 1367

la Grange, H., 244

Labyrinthula terrestris, on annual bluegrass in Colorado, 919N

Lactuca sativa (lettuce)

Fusarium oxysporum f. sp. lactucae on PCR-based detection assay for, 860 soil solarization and flooding for, 1323 temperature and severity of wilt, 13

Olpidium virulentus on, 563

Xanthomonas campestris pv. vitians on, in South Korea, 790N

Lagenaria mild mosaic virus (LaMMoV), in bottle gourd in Myanmar, 1225

Lagenaria siceraria (bottle gourd, calabash gourd)

Cucurbit chlorotic yellows virus in, in Taiwan, $1168 \mathrm{~N}$

Glomerella magna on, in Taiwan, 787N

Lagenaria mild mosaic virus in, in Myanmar, 1225

Lakhanpaul, S., 1265N

Lalancette, N., 126N, 1000

Lamichhane, J.R., 382N

LaMondia, J. A., 119, 134N

Lampranthus spp. N.B. Brown (figmarigold),

Verticillium dahliae on, in Italy, 129N

Lamprecht, R. L., 1348

Landa, B. B., 148, 280N

Laney, A. G., 1070N

Lang, J. M., 311

Larkin, R. P., 1491
Larsen, J., 432

Lartey, R. T., 1100, 1166N

Lasiodiplodia spp.

L. crassispora on grapevine in California, $785 \mathrm{~N}$ in South Africa, 1063N

L. theobromae, in southern highbush blueberry, 966

Lassois, L., 648

Late wilt, Cephalosporium maydis on corn, in Portugal and Spain, 379N

Latisnere-Barragan, H., $488 \mathrm{~N}$

Latuca sativa (lettuce), Sclerotinia sclerotiorum in, 1118

Laurel wilt, Raffaelea lauricola on redbay in Mississippi, 634N

Laurent, A., 1264N

Lauriault, L. M., 638N

Lavandula spp.

L. pubescens, Fusarium oxysporum on, in Saudi Arabia, 1163N

L. stoechas Alfalfa mosaic virus in, in Italy, $924 \mathrm{~N}$ Botrytis cinerea on, in Italy, $380 \mathrm{~N}$

Lavender. See Lavandula stoechas

Lawande, K. E., 1066N

Lawrence, A. M., 126N

Lawrence, T., 1367

Layton, B., 634N

Lazarovits, G., 201

LBVaV. See Lettuce big-vein associated virus

le Roux, H. F., 244

Le Roux, J., 478N

Leach, J. E., 311

Leatherleaf fern. See Rumohra adiantiformis

LeBoldus, J. M., 1238

Lebsky, V., 1266N

Lecoq, H., 1378N

Lee, E., $1264 \mathrm{~N}$

Lee, H. B., $1372 \mathrm{~N}$

Lee, K.-W., 1225

Lee, L. M., 637N

Lee, R. F., 781N

Lee, S. W., 271N, 790N, 1164N

Lee, W.-S., 1263N

Lee, Y. H., 790N

Lee, Y.-K., 1164N

Leek. See Allium porrum

Lefeuvre, P., 993

Legorburu, F. J., 635N

Leguay, A., 633N

Lembicz, M., 1372N

Lemmetty, A., 639N

Lemon balm. See Melissa officinalis

Lens culinaris (lentil) Aphanomyces euteiches on, in Idaho, 480N Stemphylium botryosum on, temperature and wetness, 1219

Lenssen, A. W., 1100

Lentil. See Lens culinaris

León, M., 534, 1170N

Lepidium draba, Colletotrichum higginsianum in, in Europe, $1166 \mathrm{~N}$

Leptosphaeria maculans, on cabbage in Mexico, $791 \mathrm{~N}$

Lettuce. See Lactuca sativa

Lettuce big-vein associated virus (LBVaV), Olpidium virulentus in lettuce and, 563

Leuchtmann, A., 1372N

Leveillula taurica on giant blazing star, $132 \mathrm{~N}$

on onion in Iran, $280 \mathrm{~N}$

Levi, A., 1195

Levy, L., 959

Lewandowski, D. J., 542

Leyva-López, N. E., 388

Li, B., 482N

Li, B.-J., $1377 \mathrm{~N}$

Li, C.-P., 916N, 919N

Li, D. W., 134N

Li, D.-W., $1166 \mathrm{~N}$ 
Li, G., 221

Li, G. Q., 45

Li, G. Y., 378N

Li, H. L., $1505 \mathrm{~N}$

Li, H.-X., 551

Li, J. Z., 641N

Li, J.-F., 919N

Li, J.-Q., 373N

Li, J.-T., $1168 \mathrm{~N}$

Li, K., 351

Li, M., 915N

Li, Q., 221

Li, S., 1035

Li, S. B., $641 \mathrm{~N}$

Li, S. C., $641 \mathrm{~N}$

Li, S. Y., 1378N

Li, W., 87, 959

Li, X., 45, 376N, 796

Li, Y., 1266N

Li, Y. H., $1171 \mathrm{~N}$

Li, Y. Z., 484N

Li, Z., 977

Li, Z. A., $375 \mathrm{~N}$

Li, Z. F., 45

Li, Z. Y., $484 \mathrm{~N}$

Li. , B. -J., $127 \mathrm{~N}$

Liao, J. L., $271 \mathrm{~N}$

Liao, J.-Y., 1267N

Liefting, L. W., 479N

Lilium spp.

Phytophthora nicotianae on, in China, $782 \mathrm{~N}$ viruses in, in Argentina, 1188

Lily, Pyricularia grisea on, in Korea, 280N

Lily mottle virus (LMoV), in lily in Argentina, 1188

Lily symptomless virus (LSV), in lily in Argentina, 1188

Lim, K. B., $280 \mathrm{~N}$

Lima, J. A. A., 1206

Limber Pine Dwarf Mistletoe. See Arceuthobium cyanocarpum (limber pine dwarf mistletoe)

Lin, B. R., 640N

Lin, C. H., 481N

Lin, Y., 201

Linaldeddu, B. T., 919N, 1068N

Ling, K. -S., 325

Ling, K.-S., 1376N

Liou, R. F., $128 \mathrm{~N}$

Liu, C. W., $481 \mathrm{~N}$

Liu, D. Q., 45

Liu, H., 1441

Liu, H. L., 131N, 1062N

Liu, H.-Y., 640N

Liu, J., 977

Liu, J. L., $1508 \mathrm{~N}$

Liu, L. Z., $485 \mathrm{~N}$

Liu, T. G., $1163 \mathrm{~N}$

Liu, X., 1137

Liu, X.-B., $916 \mathrm{~N}$

Liu, Y., $1377 \mathrm{~N}$

Liu, Y. Q., $922 \mathrm{~N}$

Liu, Y. T., 484N

Liu, Z. H., 480N

Lo Giudice, V., 1372N

Lobin, K., 1261N, 1373N

Loblolly pine. See Pinus taeda

Lockhart, B. E., 374N, 921N

Loconsole, G., 482N

Loh, M. H., $1068 \mathrm{~N}$

Long, D. L., 775

Long, R. P., 1026

Longidorus elongatus, in Canada, $782 \mathrm{~N}$

Lopes, S. A., 244

Lopes, U. N., $1378 \mathrm{~N}$

Lopes, U. P., 1378N

López, A., 784N

López, A. C., 487N, 1064N

López, M. M., 786N

López, N., $1507 \mathrm{~N}$

López-Escudero, F. J., 382N
Loquat. See Eriobotrya japonica

Lorbeer, J. W., 916N

Lorber, J. D., 1167N

Lorenzen, J., 1384

Lorito, M., 928

Louws, F. J., 1015

Lr14a gene, and Puccinia triticina in durum wheat, $1068 \mathrm{~N}$

Lr32 gene from Puccinia triticina, virulence of, in South Africa, 381N

LSV. See Lily symptomless virus

Lu, S.-E., 1431

Lu, Z. H., 641N

Lübeck, M., 432

Lucena, C., $280 \mathrm{~N}$

Luffa cylindrica, Glomerella magna in, in Taiwan, 787N

Luo, L.-X., 373N

Luo, Z., 977

Luo, Z. X., 1503N

Luongo, L., 134N, 484N, 791N

Lupinus spp.

L. albus, Brenneria quercina pathovar on, 1431

L. angustifolius, Phytophthora cinnamomi on, mefenoxam sensitivity and, 39

Luque, A. G., 1411

Lv, C.-C., 373N

Lv, H., 87

Lv, R., 1231

Lycianthes rantonnetii, Tomato apical stunt viroid in, in Netherlands, $791 \mathrm{~N}$

Lynch, S. C., 1510N

Lynn-Patterson, K., 827

Ma, J., 1088

Ma, Z., 873, 1137

Macadamia quick decline (MCD), Phytophthora tropicalis and, in Hawaii, 128N

Maccaferri, M., 420

Maccarone, L. D., 563

Maccheroni, W., $1170 \mathrm{~N}$

MacDonald, J. D., 320

Machado, A. C. Z., 790N

Machado, M. A., 283

Macrophomina phaseolina, in soybean, conidia production by isolates in culture, 1088

Madagascar periwinkle. See Catharanthus roseus (vinca)

Madden, L. V., 265, 1026

Magnano di San Lio, G., 1374N

Magnano di San Lio, R., 1372N

Mahaffee, W. F., 58

Mahran, A, 1510N

Maize dwarf mosaic virus (MDMV), in corn, 1093

Majil, V. M., 781N

Malik, A. H., 276N

Malinoski, M. K., 279N

Mallik, I., 130N, 1506N

Malumphy, C., 510

Malus spp.

M. domestica (apple)

Botrytis spp. on, resistance to pyraclostrobin and boscalid, 604 Gymnosporangium yamadae on, in North America, 1169N

Penicillium spp. on, in South Africa, wet core rot and, 666

Venturia inaequalis on, in Indiana, benzimidazole resistance, 744

M. toringo (crabapple), Venturia inaequalis on, in Indiana, benzimidazole resistance, 744

Malva vein clearing virus (MVCV), in hollyhock in Germany, 276N, Cover photo: February

Malvick, D., 1064N

Malvick, D. K., 1069N

Mamane. See Sophora chrysophylla

Manandhar, H. K., 298
Mancozeb, past, present, and future of, 1076

Mandarin rind disorder, etiology and

management of in California, 1485

Mandevilla spp., Phytophthora spp. in, in Italy, $1374 \mathrm{~N}$

Mangifera indica (mango)

Botryosphaeria dothidea and Neofusicoccum mangifera on, in Taiwan, $128 \mathrm{~N}$

Verticillium dahliae on, in Spain, 380N

Mango. See Mangifera indica

Manihot esculenta (cassava)

Bipolaris setariae on, in China, 919N

Corynespora cassiicola on, in China, $916 \mathrm{~N}$

Manimekalai, R., 636N, 1376N

Manjunath, K. L., 781N

Mansilla, J. P., 635N

Mansilla Vázquez, J. P., 273N

Mansoor, S., 276N

Mansour, M. F., 250

Manter, D. K., 1329

Mantovani, P., 420

Mao, X. Q., 1510N

Maoka, T., 1248

Marais, A., 477N, 633N

Maranta spp.

M. arundinacea (arrowroot), Meloidogyne enterolobii on, in China, $271 \mathrm{~N}$

M. leuconeura erythroneura (red-veined prayer plant), Sugarcane mosaic virus on, in Florida, 378N

Marasmiellus mesosporus, in seashore parspalum in Dominican Republic, 1374N

Marcum, D. B., 276N

Margosan, D. A., 250

Marinangeli, P. A., 1188

Marisch, F., 133N

Markakis, E. A., 1156

Markell, S., 273N

Markell, S. G., 789N

Marmalade bush. See Streptosolen jamesonii

Marois, J. J., 258, 1336

Martin, F. N., $131 \mathrm{~N}$

Martin, R. R., 4, 376N, 1132

Martin, T., $1510 \mathrm{~N}$

Martin, T. J., 1125

Martinez, G., 1163N

Martínez-Gómez, P., 275N

Martín-Sanz, A., 128N

Maruta, Y., 1248

Maruthasalam, S., $481 \mathrm{~N}$

Mason, S. L., 374N, 921N

Masuka, A. J., 1067N

Mateos, A., 379N

Matheron, M. E., 1118, 1323

Mathew, F. M., 789N

Mathews, D. M., 163

Mathiasen, R., 134N, 377N, 635N

Matoh, T., 812

Mauzey, S. J., 1375N

Mavric Pleško, I., $1171 \mathrm{~N}$

Mayfield III, A. E., 634N

Maymon, M., $1506 \mathrm{~N}$

Mazzola, M., 835

MBI-D fungicides. See Melanin biosynthesis inhibitor targeting scytaline dehydratase

Mbofung, G. C. Y., 860

McBeath, J. H., 132N

McDonald, S. J., 1379N

McFarland, K., 126N

McFarland, K. A., 1000

McGourty, G., 717

McGrath, M., 1063N

McGrath, M. T., 1461

McLeod, A., 666, 1461

Meacham, T. M., 1262N

Medel, R., 784N

Medicago polyceratia. See Cicer arietinum

Medina, V., 1448

Medina-Hernandez, D., 1266N

Mediterranean fan palm. See Chamaerops humilis L. 
Mefenoxam, Phytophthora spp. and $P$. capsici resistance, 1461

$P$. cinnamomi isolates on Lupinus angustifolius, sensitivity to, 39

$P$. nicotianae on tobacco in Virginia, sensitivity to, 1355

Meitz, J. C., 1461

Mekuria, T. A., 784N, 787N

Melaleuca quinquenervia, Puccinia psidii in, in Florida, 1165N

Melanin biosynthesis inhibitor targeting scytaline dehydratase (MBI-D), Pyricularia oryzae resistance to, changes in after

discontinuance of, 329

Melanson, R. A., 465

Melcher, U., 75

Melero-Vara, J. M., 379N

Melgar, J. C., 376N

Melgarejo, P., 1048

Melissa officinalis (Lemon balm),

Golovinomyces biocellatus on, in Hungary,

1169 N, Cover photo: September

Mello, A. F. S., 75

Mello, A. P. O. A., $1066 \mathrm{~N}$

Meloidogyne spp. (root-knot nematodes)

M. brasilensis on tomato in Brazil, $M i$ resistance gene and, $781 \mathrm{~N}$

M. enterolobii, on arrowroot in China, $271 \mathrm{~N}$

M. incognita

in watermelon, grafting root stock for management of, 1195

on tomato, grafting to manage diseases from, 1015, Cover photo: August

in wild Solanum accessions, multiple resistance to, 179

Melon necrotic spot virus (MNSV)

in melons, Olpidium bornovanus and, 163

Melton, T., 613

Melton, T. A., 455

Melzer, M. J., 196, 641N, 921N, 1508N

Men, R., 379N

Méndez-Lozano, J., 388

Meng, Q. F., 45

Mentha spp. (mint)

Golovinomyces biocellatus on

in California, M. piperita (peppermint), $276 \mathrm{~N}$

in Italy, M. spicata (spearmint), 1171N

Verticillium dahliae on, 1255

viruses in, 4

Mentzelia laevicaulis (giant blazing star),

Leveillula taurica on, 132N

Menzel, W., 276N, 788N

Mestries, E., 1398

Mészáros, K., 1062N

Metalaxyl, for Phytophthora sojae in soybean in China, 873

Methley plum. See Prunus cerasifera $\times P$. salicina

Methyl benzimidazole carbamates (MBC), $1511 \mathrm{~N}$

Mexican fan palm. See Washingtonia robusta

Mexican lime, and Candidatus Liberibacter asiaticus in Belize, $781 \mathrm{~N}$

Mexican spruce. See Picea mexicana

Meyer, J. B., 244

Meyer, M. D., 1093, 1111

Mi resistance gene, from root-knot nematode, Meloidogyne brasilensis in tomato in Brazil, $781 \mathrm{~N}$

Michelutti, R., 634N, 916N

Michereff, S. J., 278N, 1506N

Microascus cirrosus, on pistachio in Iran, 642N

Microbotryum violaceum, on Silene latifolia, Cover photo: May

Microstegium vimineum (Japanese stiltgrass),

Bipolaris sp. for control of, 807

Miklas, P. N., 885

Mikona, C., 471

Mila, A. L., 613
Milgroom, M. G., 1461

Miller, G. L., 1374N

Miller, S., 1510N

Miller, S. A., 109

Miller, W. P., 1213

Mills, D., 820

Minnis, A. M., 279N, 293

Mint. See Mentha spp.

Mirabolfathy, M., 278N

Mirafiori lettuce big-vein virus (MLBVV),

Olpidium virulentus in lettuce and, 563

Mirzaee, M. R., 280N, 642N

Misaghi, I. J., 163

Miscanthus $\times$ giganteus, Pithomyces chartarum on, in Kentucky, 480N

Mistletoe. See Arceuthobium spp.

Miyakazi, K., 358

Mizubuti, E. S. G., 1506N

Mizutani, T., 1225

MLBVV. See Mirafiori lettuce big-vein virus

Mlikota Gabler, F., 250

Mmbaga, M. T., $1266 \mathrm{~N}$

Mohamed, D., 1379N

Mohammadi, M., 127N, 280N, 642N

Mohan, S. K., 132N, 380N

Mojtahedi, H., 918N

Mold. See Grain mold

Molinero-Ruiz, M. L., 379N

Molineros, J. E., 265

Møller, K., 432

Mollov, D., 1064N

Mollov, D. S., $921 \mathrm{~N}$

Molnar, T. J., $1265 \mathrm{~N}$

Momen, B., 596

Momordica charantia (balsam pear, bitter gourd)

Cornyespora cassiicola on, in China, $127 \mathrm{~N}$

Tomato leaf curl Palampur virus in, in Pakistan, $276 \mathrm{~N}$

Monfort, W. S., $1168 \mathrm{~N}$

Mongkolporn, O., 306

Monilia polystroma, on plum in China, $478 \mathrm{~N}$

Monilinia spp.

M. fructicola

on apricot in Switzerland, 643N

on peach: in New Jersey, resistant to demethylation inhibitor fungicides, $126 \mathrm{~N}$; QoI fungicides and, 1000; in Slovenia, 1166N; in South Carolina, $\beta$ tubulin E198A allele and fungicide resistance, $1511 \mathrm{~N}$; in Spain, primary inoculum sources of, 1048 on peach and nectarine, reduced sensitivity to fungicides, 737, 1366

M. laxa, on tart cherry in New York, $783 \mathrm{~N}$

Monosporascus cannonballus, on watermelon in Brazil, 278N

Montecchio, L., 133N

Monterey pine. See Pinus radiata

Montri, P., 306

Moon, S. Y., 271N, 790N

Moore, J. W., 589

Moorman, G. W., 39, 1355

Moral, J., 382N

Morales, F. J., 510

Moreno, M. M., 277N

Moreno, M. V., 783N

Moreno-Rico, O., 791N

Moriones, E., 179

Moro blood sweet orange. See Citrus sinensis

Mossahebi, G. H., 127N

Mostert, W., 478N

Mou, B., 640N

Moury, B., 790N

Moyer, J. W., 455

Mrazkova, M., 272N

Msallem, M., 636N

Mulrooney, R. P., 133N

Munda, A., 1166N

Munyaneza, J. E., 639N

Murraya spp.
Candidatus Liberibacter asiaticus in, and huanglongbing, 528

Murugan, S., 781N

Musa spp. (banana)

crown rot of, preharvest factors involved in postharvest disease, 648

Dickeya sp. on, in China, 640N

Fusarium oxysporum f. sp. cubense on, in India, $1379 \mathrm{~N}$

fuzzy pedicel on, 621

Xanthomonas campestris pv. musacearum on, PCR assay for detection of, 109

Mustaffa, M. M., 1379N

MVCV. See Malva vein clearing virus

Mwakutuya, E., 1219

Mycosphaerella spp.

M. brassicicola, on vegetable brassica crops,

risk assessment for, 851

M. nawae, on persimmon, leaf spot and, $374 \mathrm{~N}$

Mycovellosiela oryzae, on rice in Texas, $639 \mathrm{~N}$

Myrothecium roridum

on bean in China, $127 \mathrm{~N}$

on hydrangea in U.S., $1266 \mathrm{~N}$

Mysliwiec, T. H., 1379N

Myung, I. -S., 271N

Myung, I.-S., 790N, 1164N

Naderpour, M., 127N

Nagao, M., 128N

Nagle, A. M., 1026

Naidu, R. A., 478N, 784N, 787N

Naito, S., 515

Najar, A., $1068 \mathrm{~N}$

Nakajima, T., 329

Nakhla, M. K., 959

Nanovirus, Pea necrotic yellow dwarf virus on pea in Germany, 642N

Narváez, D. F., 258

Nascimento, A. K. Q., 1206

Nascimento, A. L. L., 1206

Nascimento, R. J., 1506N

Nasturtium. See Tropaeolum majus

Nasturtium officinale (watercress), Turnip

mosaic virus on, in Brazil, 1066N

Natsuaki, K. T., 1225

Navas-Cortés, J. A., 148, 280N

Nectarine, Monilinia fructicola in, in South

Carolina and Georgia, reduced sensitivity to fungicides, 737, 1366

Neher, O. T., $372 \mathrm{~N}$

Nel, L. H., 1348

Nelson, A. H., 1009

Nelson, B. D., 1299

Neofusicoccum spp.

N. macroclavatum, on grapevine in New Zealand, 1504N

N. mangiferae, on mango in Taiwan, $128 \mathrm{~N}$

N. mediterraneum on grapevine in California, $785 \mathrm{~N}$ on walnut in California, $1267 \mathrm{~N}$

N. parvum on Asian pear in Taiwan, $1062 \mathrm{~N}$ on Chinese weeping cypress in China, $641 \mathrm{~N}$

$N$. ribis, on southern highbush blueberry, 966

$N$. vitifusiforme, on blueberry in China, $1373 \mathrm{~N}$

Nerium oleander (oleander), Xylella fastidiosa on, in Louisiana, $274 \mathrm{~N}$

Ngachan, S. V., 126N

N'Guessan, C. A., 1378N

Ni, H. F., $128 \mathrm{~N}$

Nian, G. L., $1505 \mathrm{~N}$

Nico, A. I., 148

Nicotiana spp. (tobacco)

N. longiflora, Phytophthora nicotianae on, in North Carolina, 557

N. occidentalis, transmission of Grapevine leafroll-associated virus-7 to by Cuscata europea, 471 


\section{N. tabacum}

Phytophthora nicotianae on: population structure, mating type, and mefenoxam sensitivity, 1355; resistance against, 455

Phytophthora parasitica var. nicotianae on, chemical control, cultivar resistance, cultivar root system structure and, 613

Pythium myriotylum on, in Zimbabwe, $1067 \mathrm{~N}$

Rhizoctonia spp. in, in Greece, 1314

Nigro, F., 274N

Nik Masdek, H., 642N

Niknam, G., 782N

Nikolaeva, E. V., 638N

Nikolaeva, O. V., 972, 1262N

Nipoti, P., 1070N

Nishio, Z., 335

Nissinen, A., 639N

Niu, C., 792N

Njau, P. N., 413

Nogueira, D. R. S., 278N

Nolte, P., 1384

Northover, P. R., 377N

Novelli, V. M., 283

Nowaczyk, K., 920N

Núñez-Farfán, J., 1376N

Nut gray necrosis (NGN), Fusarium lateritium on hazelnut in Italy, $484 \mathrm{~N}$

Nutter Jr., F. W., 167

Nylon membrane bag assay, for effect of chemicals on soilborne plant pathogens in soil, 201

Oat. See Avena sativa

Obregón, M. A., 928

Obrêpalska- Stêplowska, A., 920N

Ocamb, C. M., 425

Ocimum basilicum (basil), Plectosphaerella tabacinum on, in U.S., 484N, Cover photo: April

Ocimum minimum (basil), Fusarium oxysporum

f. sp. basilici on, in Portugal, $1170 \mathrm{~N}$

O'Connell, S., 1015

O'Donnell, K., 31

O'Donnell, K., 1411

Ogata, D. Y., 641N

Ogris, N., 133N

Oil palm, Phytophtora palmivora on, in

Colombia, $1163 \mathrm{~N}$

Okabe, I., 1064N

Okra. See Abelmoschus esculentus

Okra yellow mosaic Mexico Virus (OkYMMV), on okra in U.S., 924N

OkYMMV. See Okra yellow mosaic Mexico Virus

Olea europea (olive)

nematodes (plant-parasitic) attacking, 148,

Cover photo: February

Phoma sp. on, in Tunisia, 636N

Phytophthora palmivora on, in Italy, 1372N, Cover photo: November

Verticillium dahliae on defoliating and non-defoliating pathotypes, 1156

in Italy, $1372 \mathrm{~N}$, Cover photo: November

Oleander. See Nerium oleander

Olivares-García, C., 396

Olive. See Olea europea

Oliveira, H., 1504N

Olmos, A., 635N

Olpidium spp.

O. bornovanus, on melons, pathogenicity

and management, 163

O. virulentus, in lettuce, 563

Olson, S., 1195

Olson, T. N., 638N

Onesto, J. P., 790N

Ong, K. L., 1377N

Onion. See Allium cepa
Orange. See Citrus sinensis

Orange coneflower. See Rudbeckia fulgida

Orchids, Impatiens necrotic spot virus in, in

China, $915 \mathrm{~N}$

Oriental paperbush. See Edgeworthia papyrifera

Ornamentals, Phytophthora ramorum in, in Serbia, 703

Orobanche ramosa (branched broomrape),

Sclerotium rolfsii on, in Chile, $1266 \mathrm{~N}$

Ortega, A., 396

Oryza sativa (rice)

Fusarium andiyazi on, in Italy, 1070N

Mycovellosiela oryzae on, in Texas, 639N

Pantoea agglomerans on, in Korea, 1372N

Pantoea ananatis on, in China, $482 \mathrm{~N}$

Rhizoctonia oryzae-sativae on

in California, diversity among isolates, 690

natural plant products for control of, 986

Ustilaginoidea virens on, furrow irrigation and, 563

Osborne, L., 789N

Owens, K. J., 959

Oxytetracycline (OTC), Xanthomonas

arboricola pv. pruni on peach, 1213

Ozbek, H., 1374N

Özyilmaz, Ü., 923N

Padilla, C. V., 1507N

Padilla, V., 635N, 1507N

Paeonia spp.

Cucumber mosaic virus in, in France, $790 \mathrm{~N}$

Pilidium concavum on, in China, 271N

Palacio-Bielsa, A., 786N

Palágyi, A., 1062N

Pallás, V., 275N

Palmateer, A. J., 1506N

Palmero, D., 277N

Palmieri, M., 482N

Palomo, J. L., 128N

Pan, R., 485N

Pan, Z., 796

Pancaldi, D., 1070N

Pane, A., 1372N, 1374N

Panicum virgatum (switchgrass)

Bipolaris oryzae on, in Mississippi, 643N

Puccinia emaculata on, in Arkansas, 381N

Pantoea spp.

$P$. agglomerans, on rice in Kora, $1372 \mathrm{~N}$

$P$. ananatis

on corn in Argentina, 487N

on onion in New York, $916 \mathrm{~N}$ on rice in China, $482 \mathrm{~N}$

$P$. stewartii, on corn, host resistance and thresholds for use of seed-treatment insecticides, 1111, Cover photo: September

Papaya. See Carica papaya

Papaya lethal yellowing virus (PLYV), in

papaya, 1206, Cover photo: October

Papaya ringspot virus (PRSV) in snake gourd in Brazil, 789N transgenic melon for resistance to, 1341 in zucchini in Poland, $633 \mathrm{~N}$

Paper flower. See Bougainvillea glabra

Paplomatas, E. J., 1156

Pappu, H. R., 1261N, 1373N, 1508N

Paratrichodorus minor (stubby root nematodes), in China, $376 \mathrm{~N}$

Paret, M. L., 521

Park, C. S., 374N

Park, J. -H., 277N

Park, S., 638N

Parker, P. E., 725

Parks, E. J., 455

Parkunan, V., 1361

Parlavecchio, G., 131N, 274N

Parra-Terraza, S., $1376 \mathrm{~N}$

Parrella, G., 924N

Pasche, J. S., 659, 905

Pascual, A., 885
Paspalum vaginatum (seashore paspalum)

Marasmiellus mesosporus in, in Dominican

Republic, 1374N

Sclerotinia homoeocarpa on, in China, 373N

Passiflora edulis (passion fruit), Colletotrichum boninense, C. capsici, and Glomerella sp. on, in Florida, $786 \mathrm{~N}$

Pataky, J. K., 1093, 1111

Pataky, N. R., 273N, 477N, 1262N

Patchouli (Pogostemon cablin), Corynespora cassiicola on, in China, $1508 \mathrm{~N}$

Patocchi, A., 643N

Patton, A. F., 481N

Paul, P. A., 820

Paula Júnior, T. J., 361

Paulitz, T. C., 61

PBNSPaV. See Plum bark necrosis stem pitting associated virus

PC. See Pudricion del cogollo (PC)

PCN. See Globodera pallida

PCR (polymerase chain reaction)

for detection of Fusarium oxysporum $\mathrm{f}$. sp.

lactucae in lettuce, 860

for detection of Globodera spp., 959

for elm yellows phytoplasma, 1355

in planta quantification of Plasmodiophora brassicae, 432

Pea. See Pisum sativum

Pea necrotic yellow dwarf virus (PNYDV), on pea in Germany, 642N

Peach. See Prunus persica

Peanut. See Arachis hypogaea

Pear. See Pyrus calleryana; Pyrus communis (Bartlett pear); Pyrus pyrifolia (Asian pear)

Pear decline (PD), Candidatus Phytoplasma pyri on pear in Canada, 634N

Pecan. See Carya illinoinensis

Pecan bacterial leaf scorch (PBLS), Xylella

fastidiosa in pecan, insect transmission of, 465

Pectobacterium carotovora subsp. carotovora, in Chinese cabbage, HrpNEa protein of Erwinia amylovora for resistance against, 1441

Pedersen, D. K., 1262N

Pedram, M., 782N

Peduto, F., 785N, 1167N, 1267N

Peet, M. M., 1015

Peffer, N. D., 638N

Pei, G. -Q., 130N

Pelargonium capitatum (rose pelargonium), Candidatus Phytoplasma aurantifolia on, in Australia, 1264N

Pellegrino, C., 638N

Peluffo, S., 786N

Pelz-Stelinski, K., 1200

Peng, D. L., 1262N

Peng, D. X., $1508 \mathrm{~N}$

Peng, H., 1262N

Peng, J., $1166 \mathrm{~N}$

Peng, L. C., $782 \mathrm{~N}$

Peng, Y. L., $1163 \mathrm{~N}$

Penicillium spp.

on apple in South Africa, wet core rot and, 666

on pomegranate in Italy, $1066 \mathrm{~N}$

Pensa, P., 129N, 380N, 1171N

Peperomia tetraphylla, Phytophthora nicotianae in, in China, $1171 \mathrm{~N}$

Pepino mosaic virus (PepMV), in tomato seed, chemo- and thermo-therapeutic treatments and, 325

Pepper. See Capsicum annuum; Capsicum

frutescens

Pepper leaf curl disease, Tomato yellow leaf curl Thailand virus and, in Taiwan, $637 \mathrm{~N}$

Pepper veinal mottle virus (PVMV), on tomato and peppers, in Mali, 378N

Pequi. See Caryocar brasiliense

Percich, J. A., 1069N

Pereira, O. L., 1378N

Pereira-Carvalho, R. C., 179 
Perez, F., 1063N

Perez, K., 276N

Pérez de la Vega, M., 128N

Pérez- Martínez, J. M., 621

Perez-Egusquiza, Z., 479N

Pérez-Sierra, A., 374N, 534

Pérez-Vega, E., 885

Peronosclerospora sorghi, resistance to in sorghum, in mini-core germplasm collection, 439

Peronospora tabacina, in tobacco, January temperatures and prediction of severity, 119

Perrone, G., 483N, 1509N

Persea borbonia (redbay), Raffaelea lauricola on, in Mississippi, 634N

Persian walnut. See Juglans regia

Persimmon. See Diospyros kaki

Persley, D. M., 486N

Pertot, I., 575

Perveen, K., 1163N

Pestalotiopsis microspora, in hidcote in Japan, $1064 \mathrm{~N}$

Peters, D., 1070N

Pethybridge, S. J., 1305

Petrzik, K., 1071N

Pettersen, R. I., 339, 1105

Petunia spp.

and Tobacco mosaic virus-contaminated

tools, search for disinfectants for, 542

Tomato chlorotic dwarf viroid in, in

Slovenia, $1171 \mathrm{~N}$

Phacidiopycnis washingtonensis, in persimmon

in Italy, $788 \mathrm{~N}$, Cover photo: June

Phakopsora pachyrhizi

culturing in detached leaves, urediniospore survival, temperature and humidity and, 1453

on kudzu in Illinois, $477 \mathrm{~N}$

on soybean

effects of surface wetness on, 258

understanding risk in different regions of world, 796

uredinisopores of, rainfall runoff and, 1336

Phalaenopsis spp., Impatiens necrotic spot virus in, in China, $915 \mathrm{~N}$

Phalaris paradoxa (hood canarygrass), Septoria phalaridis on, in Iran, 375N

Phaseolus vulgaris (bean)

kidney bean little leaf disease associated with, in China, $132 \mathrm{~N}$

Myrothecium roridum on, in China, $127 \mathrm{~N}$

Phytophthora capsici on, in Connecticut,

$134 \mathrm{~N}$

Sclerotinia sclerotiorum on within-row distance between plants and, 361

in Spain, screening for resistance to, 885

Sida golden mosaic virus in, in Florida, $487 \mathrm{~N}$

soybean cyst nematode and, 1299

Phellinus noxius, cross inoculation tests, in

Ryuku Islands (Japan), 358

Phialophora gregata f. sp. sojae, on soybean,

effect of monoculture on aggressiveness of, 69

Phoma spp.

on milky bellflower in Italy, $638 \mathrm{~N}$

on olive in Tunisia, $636 \mathrm{~N}$

in orange coneflower in Italy, $788 \mathrm{~N}$

$P$. macdonaldii, on sunflower, 1398

P. multirostrata, on Fuchsia $\times$ hybrida in Italy, 382N

$P$. sorghina, resistance to in sorghum, in mini-core germplasm collection, 439

Phomopsis spp., on soybean, aggressiveness of, 1026

Php gene, Phytophthora nicotianae in tobacco

in North Carolina, resistance and, 557

Phragmidium violaceum, in blackberry,

epidemiology and management of, 581

Physalis peruviana (cape gooseberry), Potato spindle tuber viroid in, in New Zealand, 479N,

Cover photo: April

Phytophthora spp.

on almond

in Spain, 534

in Turkey, $1261 \mathrm{~N}$

on Mandevilla spp. in Italy, 1374N

P. alni, on alders in Spain, 273N

$P$. cactorum, on European beech, 1009

P. capsici

on bean in Connecticut, $134 \mathrm{~N}$

on cucumber: temperature, concentration, age, algaecides and zoospore infectivity, 54; temperature, humidity, wounding and, 1417

on pepper: fungicides and host resistance for management of, 697; resistance to crown, root, fruit rot, isolate virulence and, 24

resistance of to mefenoxam, 1461

P. cinnamomi

on lupine, mefenoxam sensitivity and, 39 on white oak in Ohio, 1026

P. citricola, on European beech, 1009

$P$. citrophthora, on Buxus rotundifolia in Italy, $272 \mathrm{~N}$

$P$. cryptogea, on spinach in California, $131 \mathrm{~N}$

P. infestans

on potato tubers and emerged shoots, transmission, 18

on woody nightshade in New York, $1063 \mathrm{~N}$

P. nicotianae

on bird of paradise in Italy, 134N

on lily in China, $782 \mathrm{~N}$

on Oriental paperbush in Italy, 917N

on Peperomia tetraphylla in China,

$1171 \mathrm{~N}$

on tobacco: in North Carolina, 557;

resistance against, 455; in Virginia, population structure, mating type, and mefenoxam sensitivity, 1355

P. palmivora, on olive in Italy, Verticillium

dahliae co-infection, $1372 \mathrm{~N}$, Cover photo:

November

$P$. parasitica var. nicotianae on tobacco, chemical control, cultivar resistance, cultivar root system structure and, 613

$P$. plurivora

on European beech, 1009

on oak and other forest trees in Czech Republic, $272 \mathrm{~N}$

$P$. pseudosyringae, in chestnut in Italy, $1068 \mathrm{~N}$

P. ramorum

on California red fir in California, $1170 \mathrm{~N}$ on ornamentals in Serbia, 703

soil treatments for potential elimination of, 320

$P$. sansomeana

on corn, in Ohio, wilting and stunting, $125 \mathrm{~N}$

on soybean in China, $378 \mathrm{~N}$

$P$. sojae, on soybean

calcium for reduction of, 812

in China, 873

chloride and ammonium salts and, 758

races and virulence of, 87

resistance of commercial cultivars, 361

$P$. tentaculata, on Witloof chicory in Italy, $1504 \mathrm{~N}$

P. tropicalis

on annual vinca in Virginia, 274N and macadamia quick decline in Hawaii, $128 \mathrm{~N}$

Phytophtora palmivora, on oil palm in Colombia, $1163 \mathrm{~N}$

Phytoplasma

$16 \mathrm{SrXI}$ group, and root wilt disease of

coconut in India, 636N
16SrXII group, in potato in Turkey, 1374N

Phytotoxin, from Stemphylium solani in garlic, 1225

Pianzzola, M. J., 786N

Picea mexicana (Mexican spruce), white fir dwarf mistletoe on, in Mexico, 635N

Picea spp., Heterobasidion spp. on, annosus root disease and, 115

Pierce's disease, Xylella fastidiosa and, in California, 827

Pieris spp., Phytophthora ramorum in, in Serbia, 703

Pietersen, G., 244, 1348

Pigati, R. L., 596

Pilidium concavum, on Paeonia suffruticosa in China, 271N

Pineapple. See Ananas comosus var. comosus

Pineapple mealybug wilt-associated viruses

(PMWaVs), 196

Pinheiro, J. B., $781 \mathrm{~N}$

Pintos Varela, C., 273N

Pinus spp.

Heterobasidion spp. on, annosus root

disease and, 115

$P$. ayacahuite, Blumer's dwarf mistletoe on, in Mexico, $377 \mathrm{~N}$

P. durangensis, Arceuthobium globosum subsp. globosum on, in Mexico, 377N

$P$. lambertiana (sugar pine), Arceuthobium cyanocarpum (limber pine dwarf mistletoe) on in California, 134N

$P$. radiata (Monterey pine), Armillaria gallica on, in Hawaii, 1503N

P. sylvestris (Scots pine), Bursaphelenchus spp. on, watering regime and, 1055

P. taeda (loblolly pine), Armillaria gallica on, in Hawaii, $1503 \mathrm{~N}$

P. densiflora, Bursaphelenchus xylophilus on, in Korea, $922 \mathrm{~N}$

Piper betle (betelvine), Acidovorax avenae subsp. citrulli on, in Taiwan, $1065 \mathrm{~N}$

Pistacia vera (pistachio)

Microascus cirrosus on, in Iran, $642 \mathrm{~N}$

Verticillium dahliae on, in Spain, 382N

Pisum sativum (pea)

Ascochyta pisi on, in South Dakota, 789N, Cover photo: June

Pea necrotic yellow dwarf virus in, in

Germany, 642N

Pseudomonas syringae on, in Turkey, 923N

Pseudomonis viridiflava on, in Spain, $128 \mathrm{~N}$

Pitahaya. See Hylocereus undatus

Pithomyces chartarum, on Miscanthus $\times$

giganteus in Kentucky, 480N

Plasmodiophora brassicae, in planta quantification of, signature fatty acids, PCR 432

Plasmopara viticola, in grapevine early warning system for, 709 sage extract for control of, 575

Plectosphaerella tabacinum, on basil in U.S., $484 \mathrm{~N}$, Cover photo: April

Pleospora herbarum, on asparagus, environment and airborne spore concentrations, 843

Ploetz, R. C., 621, 786N, 1065N

Plum. See Prunus aitianli; Prunus domestica

Plum bark necrosis stem pitting-associated virus (PBNSPaV), on apricot in Spain, 275N

Plumeria spp., Coleosporium plumeriae on, in Louisiana and Malaysia, 272N

PMWaVs. See Pineapple mealybug wiltassociated viruses

PNYDV. See Pea necrotic yellow dwarf virus

Poa annua (annual bluegrass)

Colletotrichum cereale on azoxystrobin resistance, 751

$\beta$-tubulin 2 gene, thiophanate-methyl resistance and, 207

Labyrinthula terrestris on, in Colorado, $919 \mathrm{~N}$ 
Waitea circinata on

in British Columbia, 277N

in West Virginia, 1379N

in Wisconsin and Minnesota, 1165N

Podosphaera spp.

$P$. leucotricha, on callery pear in North

America, 279N

$P$. pannosa, on roses

continuous lighting and, 339

light-emitting diodes for suppression of sporulation, 1105

Poghosyan, A., 1266N

Poinsettia. See Euphorbia pulcherrima

Poinsettia flat stem disease, and phytoplasma in

Korea, 791N

Poliakoff, F., 633N

Polizzi, G., 125N, 131N, 274N, 275N, 483N, $486 \mathrm{~N}, 1509 \mathrm{~N}$

Polomski, J., 1055

Polston, J. E., 940

Pomegranate. See Punica granatum

Populus spp.

Apioplagiostoma populi on, in Canada, $377 \mathrm{~N}$

Septoria musiva on, spore suspensions and, 1238

Porchas, M., 1323

Poromarto, S. H., 1299

Porter, L. D., 480N

Pospieszny, H., 633N, 920N

Postman, J. D., 4, 461

Postnikova, E. N., 528

Potato. See Solanum acaule; Solanum tuberosum

Potato aucuba mosaic virus, in potato, cDNA microarray for detection of, 1248

Potato cyst nematode. See Globodera pallida; Globodera rostochiensis (potato cyst nematode)

Potato leafroll virus, in potato, cDNA microarray for detection of, 1248

Potato mop-top virus (PMTV), in potato cDNA microarray for detection of, 1248 in North Dakota, 1506N in Poland, $920 \mathrm{~N}$

Potato spindle tuber viroid (PSTVd) in cape gooseberry in New Zealand, 479N, Cover photo: April

in tomato in U.S., $1376 \mathrm{~N}$

Potato virus $Y$ (PVY) as evolving concern in U.S. and Canada, 1384, Cover photo: December in potato in Mexico, $1262 \mathrm{~N}$

Potato viruses $A, M, S, X$, cDNA microarray for detection of, 1248

Poudel, B., 1070N

Powell, C. A., 201

Pratt, P. D., 1165N

Pratylenchus spp.

$P$. brachyurus, host status of cover crops for, 1022

P. zeae, in pequi in Brazil, $790 \mathrm{~N}$

Pretorius, M. C., 244

Pretorius, Z. A., 381N, 784N

Pribylová, J., 1071N

Price, J. A., 659, 766, 771

Prior, P., 1264N

Procymidone, Botrytis cinerea and, multiple

resistance and, 551

Propiconazole

on Monilinia fructicola in New Jersey, resistance to, $126 \mathrm{~N}$

Sclerotinia homoeocarpa in creeping bentgrass, 596

PRSV. See Papaya ringspot virus

Prunus spp.

$P$. aitianli (dwarf sweet plum), Monilia polystroma on, in China, $478 \mathrm{~N}$

P. armeniaca (apricot) Monilinia fructicola on, in Switzerland, $643 \mathrm{~N}$ plum bark necrosis stem pittingassociated virus and apricot latent virus in, in Spain, $275 \mathrm{~N}$

$P$. cerasifera $\times$ P.salicina (Methley plum),

Armillaria gallica on, in Hawaii, 1503N

$P$. cerasus (tart cherry), Monilinia laxa on, in New York, 783N

P. dulcis (almond)

Phytophthora spp. in: in Spain, 534; in

Turkey, $1261 \mathrm{~N}$

Xylella fastidiosa and, in California, alfalfa as vector source and, 827

$P$. persica (peach)

Candidatus Phytoplasma asteris'-related strain in, in Canada, 916N

Monilinia fructicola on: in New Jersey, resistant to demethylation inhibitor fungicides, 126N; QoI fungicides and, 1000; in Slovenia, 1166N; in South Carolina and Georgia, reduced sensitivity to fungicides, 737,1366 ; in Spain, primary inoculum sources of, 1048; $\beta$-tubulin E198A allele and fungicide resistance, $1511 \mathrm{~N}$

Xanthomonas arboricola pv. pruni on, oxytetracycline for, 1213

$P$. avium (sweet cherry)

Calosphaeria pulchella on, in California, $1167 \mathrm{~N}$

Cherry leafroll virus in, in Washington, $1067 \mathrm{~N}$

Cucumber mosaic virus in, in China, $1378 \mathrm{~N}$

Pseudomonas syringae pv. syringae on, in Oregon, resistance and, 345

P. domestica (plum), Apple mosaic virus in, in Turkey, $641 \mathrm{~N}$

Pruvost, O., 993, 1069N, 1264N

Pryor, B. M., 860, 1118

Psammotettix striatus, wheat blue dwarf disease and, 977

Pseudoananus spp., pineapple mealybug wiltassociated viruses in, 196

Pseudocercospora ixoricola, on Ixora coccinea in Brazil, 278N

Pseudomonas spp.

P. cannabina pv. alisalensis, on Brussels sprouts in California, $1375 \mathrm{~N}$

P. syringae pv. alisalensis, on broccoli and cabbage in South Carolina, 132N

$P$. syringae pv. pisi, on pea in Turkey, $923 \mathrm{~N}$

$P$. syringae pv. syringae, on sweet cherry in Oregon, resistance and, 345

$P$. syringae pv. tomato, on tomato in Portugal, 1504N

$P$. viridiflava on pea in Spain, $128 \mathrm{~N}$ in rape in South Korea, 1164N

Pseudoperonospora spp.

P. cubensis, on Trichosanthes cucumerina in Malaysia, $642 \mathrm{~N}$

$P$. humuli, on hop, forecasting and management of, 425

PSTVd. See Potato spindle tuber viroid (PSTVd)

Psyllid yellows. See Tomato psyllid yellows

$\mathrm{Pu}$, X. M., 640N

Puccinia spp.

$P$. coronata f. sp. avenae, on oat, and broadspectrum resistance, 1405, Cover photo: December

P. emaculata, on switchgrass in Arkansas, $381 \mathrm{~N}$

P. graminis f. sp. tritici, on wheat sources of resistance to, 413 in South Africa, virulence to the $\mathrm{Sr} 24$ and $S r 31$ resistance genes, $784 \mathrm{~N}$

$P$. helianthi, on sunflowers in Illinois, $273 \mathrm{~N}$

$P$. jaceae var. solstitialis, on yellow starthistle, for biological control, 174

$P$. melanocephala, in sugarcane in Brazil,
$1170 \mathrm{~N}$

$P$. psidii, on Melaleuca quinquenervia in Florida, $1165 \mathrm{~N}$

$P$. similis, on sagebrush in Idaho and

Oregon, 380N

$P$. sparganioides, on Spartina alterniflora in Louisiana, 636N

P. striiformis f. sp. tritici

SCAR markers for detection of races CYR32 and CYR33, 221

on wheat, in China, long-distance spore transport, 873

on wheat, $Y r 24(Y r 26)$ gene for resistance to, $1163 \mathrm{~N}$

P. triticina

on durum wheat, $\mathrm{Lr} 14 \mathrm{a}$ gene and, $1068 \mathrm{~N}$

Lr32 gene from, and virulence, in South Africa, 381N

on wheat: genetics of resistance, 628; physiologic specialization and, 775 ; virulence phenotypes and molecular genotypes, 420

$P$. triticinia, on wheat, seedling and slow rusting resistance, 45

Pudricion del cogollo (PC), Phytophtora

palmivora on oil palm in Colombia, $1163 \mathrm{~N}$

Pueraria montana var. lobata (kudzu),

Phakopsora pachyrhizi on, in Illinois, $477 \mathrm{~N}$

Pumpkin. See Cucurbita moschata

Punica granatum (pomegranate)

Penicillium glabrum on, in Italy, 1066N

Purcifull, D. E., 1206

Putman, A. I., 186

Putnam, M. L., 1132

Pyraclostrobin

on corn with simulated hail damage, 83 gray mold from Botrytis spp. on apple,

resistance to, 604

processing sweet corn and, 213

Pyrenophora spp.

$P$. teres, on barley in Hungary, $1062 \mathrm{~N}$ in North Dakota, 480N

P. tritici-repentis, 229

Pyrethrum. See Tanacetum cinerariifolium

Pyricularia spp.

on lily in Korea, $280 \mathrm{~N}$

MBI-D fungicides, Pyricularia oryzae

resistance after discontinuance of, 329

Pyrimenthanil, Botrytis cinerea and, multiple resistance and, 551

Pyrosequencing, of soil microbial communities in potato farms, 1329

Pyrus spp.

$P$. calleryana (callery pear, Bradford pear), Podosphaera leucotricha on, in North America, 279N

$P$. communis (Bartlett pear) Apple stem pitting virus in, in Argentina, $488 \mathrm{~N}$

Candidatus Phytoplasma pyri on, in Canada, 634N

P. pyrifolia (Asian pear), Neofusicoccum parvum on, in Taiwan, $1062 \mathrm{~N}$

Pythium spp.

on coriander in Italy, 1167N

in tobacco in Zimbabwe, 1067N

Qiang, S., 1172N

Qing, L., 637N

Qiu, H. P., 1510N

Qiu, X. L., 1373N

Qu, S., 1441

Qu, S. P., 782N

Quaglia, M., 372N

Queen palm. See Syagrus romanzoffiana

Quello, K. L., 744

Quercus spp.

Q. agrifolia (coast live oak), Diplodia

corticola on, in California, 1510N

Q. alba (white oak), Phytophthora 
cinnamomi on, in Ohio, 1026

Q. chrysolepis (canyon live oak), Diplodia corticola on, in California, $785 \mathrm{~N}$

Q. robur (oak), Phytophthora plurivora on, in Czech Republic, 272N

Quinn, B. D., 479N, 781N

Quinone outside inhibitor (QoI) fungicides on corn with simulated hail damage, 83 for Monilinia fructicola on peach, 737, 1000,1366

Quiñonez Barraza, S., 377N

Ra, D.-S., 1164N

Raffaelea lauricola, on redbay in Mississippi, $634 \mathrm{~N}$

Raja, J. A. J., 1341

Rajeev, G., 636N

Ralstonia solanacearum

on Solanum spp., 372N

on Zingiber officinale, essential oils and, 521

Ramadugu, C., 781N

Ramdial, H. A., $1375 \mathrm{~N}$

Ramie. See Boehmeria nivea

Rampersad, S. N., 1062N, 1375N

Rane, K. K., 279N

Rännäli, M., $921 \mathrm{~N}$

Rao, V. P., 439

Rapid blight, Labyrinthula terrestris on annual

bluegrass in Colorado, $919 \mathrm{~N}$

Raspberry. See Rubus idaeus

Rattlebox, showy. See Crotalaria spectabilis

Raudino, F., 1372N

Rauf, A., 478N

Rayamajhi, M. B., 1165N

Razavi, M., 375N

Redbay. See Persea borbonia

redbay ambrosia beetle. See Xyleborus glabratus

Reddy, K., 636N

Redinbaugh, M. G., 265

Red-veined prayer plant. See Maranta

leuconeura erythroneura

Reed, J. D., 1377N

Rehman, M., 376N

Reilly, C. C., 1213

Remesal, E., 280N

Renaudin, I., 633N

Resende, R. O., 179

Residue management, soilborn pathogens of cereals in irrigated cropping system and, 61

Resistance

of Alternaria dauci on carrot, 405

of Anthurium andraeanum, to Xanthomonas axonopodis pv. dieffenbachiae, 1243

to bean leaf beetle, Bean pod mottle virus and, 265

of bean to white mold, screening for, 885

to Begomovirus spp., Meloidogyne spp. in wild Solanum accessions, 179

of Botrytis cinerea

to multiple fungicides, 551

on raspberry in Serbia, fungicides and, $486 \mathrm{~N}$

Colletotrichum cereale in turf grasses, azoxystrobin resistance, 751

of corn to Pantoea stewartii subsp. stewartii, and thresholds for use of seed-treatment insecticides, 1111, Cover photo:

September

to Gibberella zeae in wheat, carbendazim and, 1137

to grain mold and downy mildew, in minicore sorghum germplasm collection, 439

HrpNEa protein of Erwinia amylovora, against Pectobacterium carotovora subsp. carotovora in Chinese cabbage, 1441

Monilinia fructicola in peach, $\beta$-tubulin E198A allele and fungicide resistance, $1511 \mathrm{~N}$

of mustards to Turnip mosaic virus, 1290,

Cover photo: November against Phytophthora spp.

$P$. capsici in pepper, 24, 697

$P$. nicotianae in tobacco, 455

$P$. sojae in soybean, in commercial cultivars, 361

of Phytophthora spp.

$P$. capsici to mefenoxam, population structure and, 1461

$P$. sojae in soybean in China, against metalaxyl, 873

P.nicotianae in tobacco in North Carolina, Php gene and, 557

to propiconazole, Monilinia fructicola in

New Jersey and, 126N

against Puccinia spp.

$P$. coronata f. sp. avenae in oat, 1405 , Cover photo: December

$P$. graminis f. sp. tritici in wheat, 413, $784 \mathrm{~N}$

P. striiformis f. sp. tritici in wheat, $\operatorname{Yr} 24$

(Yr26) gene, $1163 \mathrm{~N}$

$P$. triticina in wheat, 45

of Sclerotinia homoeocarpa to fungicides,

186, Cover photo: February

of soft red winter wheat to leaf rust, genetics of, 628

of sweet cherry to Pseudomonas syringae

pv. syringae, 345

of transgenic melon to Papaya ringspot

virus and Zucchini yellow mosaic virus, 1341

Venturia inaequalis in apple and crabapple

in Indiana, benzimidazole resistance, 744

Retief, E., 478N

Rezende, J. A. M., 374N, 789N, 1066N

Rhizoctonia spp.

on azalea, time and environmental factors, 891

on cotton and tobacco in Greece, 1314

R. AG-A (binucleate), on Thryptomene saxicola in Italy, $275 \mathrm{~N}$

$R$. oryzae-sativae, on rice

in California, diversity among isolates, 690

natural plant products for control of, 986

R. solani

on cereals in irrigated cropping system,

and tillage, residue management, and crop rotation, 61

on Ctenanthe oppenheimiana in India, $126 \mathrm{~N}$

on marmalade bush in Italy, $486 \mathrm{~N}$

on Mediterranean fan palm in Italy, $125 \mathrm{~N}$

on sugar beet, Rhizopus stolonifer and, 504

on sunflower in India, $488 \mathrm{~N}$

on throughhill yam in China, $915 \mathrm{~N}$

on tomato, in planta method for

assessing role of basidiospores in, 515

on woodland sage in Italy, 1071N

Rhizopus spp.

$R$. oryzae, on sunflower in New Mexico,

$638 \mathrm{~N}$, Cover photo: May

R. stolonifer, in sugar beet, Rhizoctonia solani and, 504

Rhododendron spp. (azalea)

Phytophthora ramorum on, in Serbia, 703

Rhizoctonia spp. on, time and environmental factors, 891

Rhouma, A., 636N

Rial Martínez, C., 273N

Ribes nigrum (gooseberry), Cronartium ribicold

in, comparative infectivity of asciospores and uredinisopores, 461

Ribes spp. (currant), Botryosphaeria ribis in, in U.S., 1283

Riccioni, L., 134N

Rice. See Oryza sativa

Richardson, K., 640N

Richardson, P. A., 274N
Richert-Pöggeler, K. R., 276N

Ridgway, H. J., 1168N

Riggins, J. J., 634N

Rigling, D., 1055

Riley, K. L., $1170 \mathrm{~N}$

Rivard, C. L., 1015

Rivera, P. A., 633N, 1067N

Rivera, Viviana V., 1272

Rivera C., J. M., 376N

Rizza, C., 1374N

Robbins, R. T., 782N

Robène-Soustrade, I., 993, 1069N, 1264N

Roberts, S. J., 298

Robertson, A. E., 167

Robertson, N. L., $372 \mathrm{~N}$

Robles-Hernández, L., 1262N

Roca, L. F., 382N

Rodríguez-Alvarado, G., 483N

Rodríguez-Fernández, R., 483N

Roenhorst, J. W., 791N, 920N

Rogan, D., 376N

Rogers, P. M., 405

Rojas, M. R., 482N

Romberg, M. K., 781N

Roncoroni, J., 717

Rooney-Latham, S., 785N

Rosa, D. D., $126 \mathrm{~N}$

Rose pelargonium. See Pelargonium capitatum

Roselló, M., 786N

Roses, Podosphaera pannosa in

light-emitting diodes for suppression of sporulation, 1105

and powdery mildew, 339

Rossi, V., 709

Rossini, M. N., 488N

Rosskopf, E. N., 201

Rossman, A. Y., 279N

Rothrock, C. S., $1168 \mathrm{~N}$

Rott, M., 1367

Roussos, P. A., 1156

Roux, J., 1143

Rouxel, T., 791N

Ruark, S. J., 445

Rubio, M., 275N

Rubus spp.

R. brasiliensis (blackberry), Colletotrichum acutatum on, in Brazil, 1378N

$R$. idaeus (raspberry), Botrytis cinerea on, in Serbia, and resistance, $486 \mathrm{~N}$

Rubus spp. (blackberry), Phragmidium violaceum on, 581

Rudbeckia spp.

Phoma sp. in, in Italy, 788N

phytoplasma infection of, Cover photo: June

Ruden, B., 789N

Ruhl, G., 484N

Rui, K., 271N

Rumohra adiantiformis (leatherleaf fern), fern

distortion syndrome in, in Costa Rica, 940

Rush, C. M., 659, 766, 771

Rymelska, N., 633N

Sabandzovic, S., $126 \mathrm{~N}$

Saborío, F., 940

Saccharomyces sp., on pineapple in Brazil, $1509 \mathrm{~N}$

Saccharum L. hybrid. See Sugarcane

Sage. See Salvia spp.

Sagebrush. See Artemisia tridentata

Sahashi, N., 358

Sahin, F., 1374N

Saison, A., 1069N, 1373N

Salati, M., 642N

Salati, R., 482N

Salerno, G., 783N

Sales Jr., R., 278N

Salvia spp. (sage)

S. nemorosa, Rhizoctonia solani on, in Italy, $1071 \mathrm{~N}$

S. officinalis, extract from, control of powdery mildew in grapevines and, 575 
Samad, A., 4

Sampangi, R. K., 132N, 380N

Samuels, G. J., 928

Sánchez, E., 940

Sánchez-Navarro, J. A., 275N

Sánchez-Peña, P., 1376N

Sanderlin, R. S., 465

Sanford, D. L., 1379N

Sanguino, A., 1170N

Sanjuán, S., 1264N

Sanogo, S., 638N

Santana, C. V. S., $278 \mathrm{~N}$

Santori, A., 484N, 791N

Santos-Cervantes, M. E., 388

Saponari, M., 482N

Sariah, M., 642N

Sarria, G. A., $1163 \mathrm{~N}$

Sasikala, M., 636N

Sathish Kumar, R., 636N, 1376N

satkara. See Citrus macroptera

SbBMV. See Soybean blotchy mosaic virus

Scandiani, M. M., 1411

Scanu, B., 919N, 1068N

SCAR markers, for detection of CYR32 and

CYR33 races of Puccinia striiformis f. sp. tritici, 221

Schaad, N. W., 528

Scherm, H., 891, 1213

Schillinger, W. F., 61

Schmale III, D. G., 1151

Schmitt, A., 575

Schmitthenner, A. F., 758

Schnabel, G., 737, 1366, 1511N

Schneider, W. L., 528

Schroeder, B. K., 236, 1255, 1425

Schroeder, K. L., 61

Schuster, G., 481N

Schwerdtfeger, M., 244

Scibetta, S., 1374N

Sclerotinia spp.

S. homoeocarpa

on creeping bentgrass, fungicides for control of, 596

on Paspalum vaginatum in China, $373 \mathrm{~N}$

resistance to fungicides, 186 , Cover photo: February

S. sclerotiorum

on bean: within-row distance between plants and, 361; in Spain, screening for resistance to, 885

on canola: factors enhancing carpogenic germination of sclerotia, 1041; in Texas, $791 \mathrm{~N}$

on lettuce, Coniothyrium minitans for control of, 1118

on pyrethum, 1305

Sclerotium rolfsii

on branched broomrape in Chile, $1266 \mathrm{~N}$

on Canadian goldenrod in China, 1172N

on okra in Ivory Coast, 1379N

on peanut, night spraying of fungicides and, 676, 683

on pepper in southern Spain, $280 \mathrm{~N}$

on silverbush in Italy, $131 \mathrm{~N}$, cover photo: January

on tomato, grafting to manage diseases from, 1015

Scots pine. See Pinus sylvestris

Scott, A., 924N

Scott, J., $916 \mathrm{~N}$

Scott, J. C., 13

Scott, T., $1510 \mathrm{~N}$

Seabeach sandwort. See Honckenya peploides

Seashore paspalum. See Paspalum vaginatum

Seassau, C., 1398

Sechler, A., 528

Secor, Gary A., 1272

Sedum spp., Tobacco rattle virus on, in

Minnesota, 374N

Seedling blight, Rhizoctonia solani in

throughhill yam in China, $915 \mathrm{~N}$
Segarra, J., 1048

Seifbarghi, Sh., 375N

Seifers, D. L., 1125

Selvarajan, R., 636N

Sengoda, V. G., 639N

Seno, M., 1378N

Septoria spp.

$S$. erigerontis, on horseweed in Turkey, $918 \mathrm{~N}$

S. glycines, on soybean in Ohio, 820

S. musiva, on Populus spp., spore suspensions and, 1238

$S$. phalaridis, on hood canarygrass in Iran, $375 \mathrm{~N}$

Serçe, Ç. U., 1448

Serdani, M., 345

Serra, P., 129N

Sether, D. M., 196, 641N, 921N, 1508N

Sfetcu, D., 1376N

Shah, D. A., 213

Shallot latent virus (SLV), in garlic in

Argentina, 915N

Shantar, A. M., 133N

Sharma, R., 439

Shaw, D. V., 13

Shen, H. F., 640N

Shen, Y. M., 131N, 1062N

Sheppard, B., 1076

Shew, B. B., 445

Shew, H. D., 455, 557

Shi, T., 916N, 919N

Shi, Y. -X., 127N

Shi, Y.-X., 1377N

Shih, S. L., 637N

Shim, H. S., 271N, 790N, 1164N

Shimabuku, R., 641N

Shimabuku, R. S., 1508N

Shin, S.-C., 922N

Shiono, M., 812

Shorey, M., $482 \mathrm{~N}$

Showy rattlebox. See Crotalaria spectabilis

Shu, J., 1071N

Sida golden mosaic virus (SiGMV), in snap

bean in Florida, $487 \mathrm{~N}$

SiGMV. See Sida golden mosaic virus

Sigobodhla, T. E., 1067N

Silene latifolia, Microbotryum violaceum on,

Cover photo: May

Silva, K. J. P., 278N

Silverbush. See Convolvulus cneorum

Sinapis alba, seed meal soil amendments from, apple replant disease and, 835

Singer, S. D., 1283

Singh, R., 274N, 1384

Singh, R. P., 413

Singh, V., 1265N

Sirococcus clavigignenti-juglandacearum, in

butternut, molecular diagnostic assay for, 952

Sisterson, M. S., 827

Sivasithamparam, K., 563, 1041

16SrII group phytoplasma, kidney bean little

leaf disease associated with, in China, $132 \mathrm{~N}$

Skantar, A. M., 959

Slaminko, T. L., 361

SLV. See Shallot latent virus

Smart, C. D., 1461

Smilanick, J. L., 250

Smit, F. J., 666

Smith, J. A., 634N

Smith, J. P., 132N

Smith, R. J., 717

Smooth cordgrass. See Spartina alterniflora

Snake gourd. See Trichosanthes cucumerina

Soe, K., 1225

Soil

nylon membrane bag assay for effect of chemicals on plant pathogens in, 201

solarization of, for Fusarium oxysporum f. sp. lactucae in lettuce, 1323

Solanum spp.

Begomovirus spp., Meloidogyne spp. in, multiple resistance to, 179

Ralstonia solanacearum on, $372 \mathrm{~N}$

S. acaule (wild potato), Cherry leaf roll

virus in, in South America, 782N

S. dulcamara (woody nightshade),

Phytophthora infestans on, in New York, $1063 \mathrm{~N}$

S. lycopersicum (tomato)

Candidatus Liberibacter psyllaurous on, in Arizona, 376N, cover photo: March Candidatus Liberibacter solanacearum on, in U.S., $481 \mathrm{~N}$

Capsicum chlorosis virus in, in Taiwan, $1263 \mathrm{~N}$

curtoviruses in, curly top disease and, 99

Fusarium oxysporum f. sp. lycopersici on, in Mexico, $1376 \mathrm{~N}$

Meloidogyne brasilensis on, in Brazil,

$M i$ resistance gene and, $781 \mathrm{~N}$

Pepino mosaic virus in, chemo- and

thermo-therapeutic treatments and, 325

Pepper veinal mottle virus in, in Mali, $378 \mathrm{~N}$

Potato spindle tuber viroid in, in U.S., $1376 \mathrm{~N}$

Pseudomonas syringae pv. tomato on, in Portugal, 1504N

Rhizoctonia solani, in planta method for assessing role of basidiospores in, 515

Sclerotium rolfsii and Meloidogyne spp. on, grafting to manage diseases from, 1015, Cover photo: August

Tomato chlorotic dwarf viroid in, in France, 633N

Tomato torrado virus in: in Australia, $486 \mathrm{~N}$; in Italy, $1172 \mathrm{~N}$

Tomato yellow leaf curl virus in: in Guatemala, 482N; in Hawaii, 641N; in Mauritius, $1261 \mathrm{~N}$

Xanthomonas spp. on: genetic and pathological diversity in, 993; in Grenada, 1264N; in Pennsylvania, $638 \mathrm{~N}$

S. tuberosum (potato)

16SrXII phytoplasma group in, in Turkey, 1374N

Candidatus Liberibacter psyllaurous on, in Honduras, $376 \mathrm{~N}$

Candidatus Liberibacter solanacearum on, zebra chip disease and, 659

cDNA microarray for detection of viruses, 1248

Colletotrichum coccodes on, soil infestation, seed tuber and foliar inoculation, 905

Dickeya dadantii on, in Zimbabwe, $1263 \mathrm{~N}$

Erwinia carotovora on, in Nepal, 382N

golden potato cyst nematode on in Quebec, 1510N

Impatiens necrotic spot virus in, in Washington, $1507 \mathrm{~N}$

Phytophthora infestans on, transmission from seed tubers to emerged shoots, 18

potato cyst nematode on, in British Columbia, 1367

Potato mop-top virus in: in North Dakota, $1506 \mathrm{~N}$; in Poland, 920N

Potato virus $Y$ in: in Mexico, $1262 \mathrm{~N}$; in U.S. and Canada, 1384, Cover photo: December

purple top disease in, phytoplasmas associated with, in Mexico, 388

pyrosequencing assessment of soil microbial communities, 1329

soilborne diseases of, rotation and cover crop effects in, 1491

Tobacco rattle virus in, in North Dakota, $130 \mathrm{~N}$

Soler, A., 275N

Solidago canadensis (Canadian goldenrod), 
Sclerotium rolfsii on, in China, $1172 \mathrm{~N}$

Sophora chrysophylla (mamane), Armillaria gallica on, in Hawaii, 1503N

Sorghum bicolor

Colletotrichum sublineolum, anthracnose and, 589

resistance to grain mold and downy mildew, in mini-core germplasm collection, 439

Soro, S., 1378N, 1379N

Soto-Plancarte, A., $483 \mathrm{~N}$

Soumya, V. P., 636N, 1376N

Southern highbush blueberry. See Vaccinium corymbosum

Southern root-knot nematode. See Meloidogyne incognita

Soybean. See Glycine max

Soybean blotchy mosaic virus (SbBMV), in soybean in South Africa, 1348

Soybean cyst nematode. See Heterodera glycines

Soybean mosaic virus (SMV), on soybean, identification and distribution of strains in southern China, 351

Soybean rust (SBR), Phakopsora pachyrhizi and on kudzu, in Illinois, $477 \mathrm{~N}$ surface wetness periods and, 258 understanding risk in different regions of world, 796

Soybean sudden death syndrome (SDS),

Fusarium virguliforme in soybean in

Michigan, 1164N

Soylu, E. M., 1069N

Soylu, S., 1069N, 1448

Spadaro, D., 1066N

Špak, J., 1071N

Spartina alterniflora (smooth cordgrass),

Puccinia sparganioides on, in Louisiana, $636 \mathrm{~N}$

SPCSV. See Sweet potato chlorotic stunt virus

Spearmint. See Mentha spicata

Spencer, R. C. J., 377N

Spiderlily. See Hymenocallis littoralis

Spinach. See Spinacia oleracea

Spinach severe curly top virus (SSCTV), in spinach in Arizona, 917N

Spinacia oleracea (spinach)

Beet necrotic yellow vein virus in, in California, 640N

Phytophthora cryptogea on, in California, $131 \mathrm{~N}$

Spinach severe curly top virus in, in Arizona, 917N

Stemphylium botryosum on, in Texas, $1377 \mathrm{~N}$

Tobacco rattle virus in, in California, $125 \mathrm{~N}$, Cover photo: January

Spiroplasma citri

on carrot in Europe, 1264N

on citrus, titer and disease severity, 75

Spongospora subterranea cv. subterranea, and

Potato mop-top virus, in North Dakota, 1506N

Sporothrix spp., fuzzy pedicel on banana and, 621

Spot form net blotch (SFNB), Pyrenophora teres on barley in North Dakota, $480 \mathrm{~N}$

Spotts, R. A., 345, 666

Spruce. See Picea mexicana

Squash leaf curl virus (SLCV), in cucurbit plants in Palestinian Authority, 640N

Sr24 and Sr31 resistance genes, Puccinia graminis $\mathrm{f}$. sp. tritici in wheat in South Africa, virulence to, $784 \mathrm{~N}$

Srinivasan, K., 488N

SSCTV. See Spinach severe curly top virus

Stachybotrys chartarum, in Tillandsia tenuifolia in China, $1166 \mathrm{~N}$, Cover photo: September

Stanghellini, M. E., 163

Staples, S. M., 1348

Stea, G., 483N

Stein, L. A., 1377N

Stemphylium spp.

S. botryosum on lentil, temperature and wetness, 1219

on spinach in Texas, $1377 \mathrm{~N}$

S. solani, on garlic, phytotoxin from, 1225 Stenglein, S. A., 783N

Stenocarpella macrospora, on corn in Illinois, $1262 \mathrm{~N}$

Stensvand, A., 339, 1105

Stevenson, W. R., 405

Stewart's disease, in corn, host resistance and thresholds for use of seed-treatment insecticides, 1111, Cover photo: September

Stiller, M., 1348

Sting nematode, on soybean in Delaware, $133 \mathrm{~N}$

Stone, A. L., 528

Stowell, L., 919N

Strausbaugh, C. A., 972

Strawberry. See Fragaria $\times$ ananassa

Strawberry tree, Diplodia scrobiculata on, in

Italy, 919N

Strelitzia reginae (bird of paradise, crane

flower), Phytophthora nicotianae on, in Italy, $134 \mathrm{~N}$

Streptosolen jamesonii (marmalade bush)

Rhizoctonia solani on, in Italy, 486N

Tomato apical stunt viroid in, in

Netherlands, $791 \mathrm{~N}$

Strnadova, V., 272N

Strobilurin fungicides, processing sweet corn and, 213

Stromberg, E. L., 39

Stubby root nematode. See Paratrichodorus minor

Stuteville, D. L., 293

$\mathrm{Su}, \mathrm{T} ., 482 \mathrm{~N}$

Succinate dehydrogenase inhibitor (SdhI) fungicides, for Monilinia fructicola in peach and nectarines in South Carolina and Georgia, reduced sensitivity to, 737,1366

Sugar beet. See Beta vulgaris

Sugar pine. See Pinus lambertiana

Sugarcane

Herbaspirillum rubrisubalbicans on, in China, mottled stripe disease and, 379N

Puccinia melanocephala on, in Brazil, $1170 \mathrm{~N}$

Sugarcane mosaic virus (SCMV)

in corn, 1093

in red-veined prayer plant in Florida, $378 \mathrm{~N}$

Sugimoto, T., 812

Sugiyama, A., 1329

Sugiyama, L., 128N

Sugiyama, S., 1248

Suhard, P., 633N

Sui, C., $918 \mathrm{~N}, 1508 \mathrm{~N}$

Sullivan, M. J., 455

Sumner, P., 676, 683

Sun, B. J., $1505 \mathrm{~N}$

Sun, E. J., 487N

Sun, F., 1367, 1510N

Sun, G. C., $1510 \mathrm{~N}$

Sun, H.-Y., 551

Sun, J. W., $1505 \mathrm{~N}$

Sun, L., 1441

Sun, X. C., 637N

Sundelin, T., 432

Sunflower. See Helianthus annuиs

Supakaew, T., 306

Suthaparan, A., 339, 1105

Sutton, T. B., 634N

Suzuki, F., 329

Svircev, A. M., 634N

Sweet orange, Candidatus Liberibacter asiaticus

in Belize, $781 \mathrm{~N}$

in Ethiopia, $482 \mathrm{~N}$

Sweet potato chlorotic stunt virus (SPCSV), in sweetpotato, Bemisia tabaci and, 510

Sweetpotato. See Ipomoea batatas

Switchgrass. See Panicum virgatum

Syagrus romanzoffiana (queen palm), Fusarium oxysporum f. sp. palmarum in, in Florida, 31,
Cover photo: January

Syverson, R., 1064N

Syzygium cumini, Chrysoporthe cubensis in, in China, 1143

Tabien, R. E., 639N

Tabiki, T., 335

Taheri, H., 129N

Takata, K., 335

Tan, H. D., $1378 \mathrm{~N}$

Tan, ZQ., 379N

Tanacetum cinerariifolium (pyrethrum),

Sclerotinia sclerotiorum in, 1305

Tande, C., 789N

Tang, J., 479N

Tang, K. Z., 375N

Tang, Q., 881

Tang, W., $1172 \mathrm{~N}$

Tanio, M., 335

Tanoviæ, B., 486N

Tarnowski, T. L., 62

Tarnowski, T. L. B., 786N, 1065N, 1506N

Tart cherry. See Prunus cerasus

Tassus, X., 633N

TASVd. See Tomato apical stunt viroid

Taylor, P. W. J., 306

Taylor, R. J., 905

TCDVd. See Tomato chlorotic dwarf viroid

TCSV. See Tobacco curly shoot virus

TeBeest, D. O., 381N, 589

Tebuconazole, for Sclerotium rolfsii and Cercospora arachidicola in peanut, night spraying and, 676, 683

Teixeira, H., 361

Teixeira, L. D. D., 374N

Tello, J. C., $277 \mathrm{~N}$

Temperature

Fusarium oxysporum f. sp. lactucae on

lettuce, severity of wilt and, 13

Pepino mosaic virus in tomato seed and, 325

Peronospora tabacina, tobacco blue mold severity and, 119

Phytophthora capsici zoospore infectivity in cucumber and, 54

Tenreiro, R., 1504N

Terefe, T., 784N

Tetragonia expansa, transmission of Grapevine leafroll-associated virus-7 to by Cuscata reflexa, 471

TEV. See Tobacco etch virus

Thakur, R. P., 439

Thammiraju, S. R., 827

Thangavelu, R., 1379N

Thekopsora minima, on blueberry in South Africa, $478 \mathrm{~N}$

Thera, A. T., 372N

Thielaviopsis basicola, on soybean in Arkansas, $1168 \mathrm{~N}$

Thies, J. A., 1195

Thiophanate-methyl, resistance to in

Colletotrichum cereale, $\beta$-tubulin 2 gene and, 207

Thiophanate-methyl (THM), Botrytis cinera in table grapes and, 250

THM. See Thiophanate-methyl

Thomas, B. R., 1238

Thomas, G. V., 636N, 1376N

Thomas, J. E., 486N

Thomidis, T., $1503 \mathrm{~N}$

Thompson, D., 634N

Thrips tabaci (thrips), and Iris yellow spot virus in onion in Mauritius, $1373 \mathrm{~N}$

Throughhill yam. See Dioscorea nipponica

Thryptomene saxicola, binucleate Rhizoctonia AG-A on, in Italy, $275 \mathrm{~N}$

Tian, X. L., $1261 \mathrm{~N}$

Tian, X. S., 640N

Tillage, soilborn pathogens of cereals in irrigated cropping system and, 61

Tillandsia tenuifolia, Stachybotrys chartarum in, in China, $1166 \mathrm{~N}$, Cover photo: September 
Tillman, B. L., 898

Tinivella, F., 1076

Tisserat, N., 919N

Tisserat, N. A., 311

Tjamos, E. C., 1156

Tjamos, S. E., 1156

TLYCV. See Tomato yellow leaf curl virus

Tobacco. See Nicotiana spp.

Tobacco blue mold, January temperatures and prediction of severity, 119

Tobacco curly shoot virus (TCSV), on pepper in China, 637N

Tobacco cyst nematode (TCN), multiplex realtime PCR assay for, 959

Tobacco etch virus (TEV), in coleus in US., $921 \mathrm{~N}$

Tobacco mosaic virus (TMV), 542

Tobacco rattle virus (TRV)

in potato in North Dakota, 130N

in Sedum spp. in Minnesota, 374N

in spinach in California, $125 \mathrm{~N}$, Cover photo: January

Tobacco ringspot virus, in joe-pye weed in

Mississippi, 126N

ToChLPV. See Tomato chino La Paz virus

Toda, T., 515

ToLCPaV. See Tomato leaf curl Palampur virus

Tomaso-Peterson, M., 207, 643N, 751

Tomato. See Solanum lycopersicum

Tomato apical stunt viroid (TASVd), in

Streptosolen jamesonii and Lycianthes rantonnetii in Netherlands, $791 \mathrm{~N}$

Tomato chino La Paz virus (ToChLPV), in pepper in Mexico, Tomato yellow leaf curl virus co-infection, $1266 \mathrm{~N}$

Tomato chlorosis virus (ToCV), in sweet pepper in Brazil, $374 \mathrm{~N}$

Tomato chlorotic dwarf viroid (TCDVd) in petunia in Slovenia, $1171 \mathrm{~N}$ in tomato in France, 633N

Tomato leaf curl Palampur virus (ToLCPaV), on bitter gourd in Pakistan, 276N

Tomato psyllid yellows, $376 \mathrm{~N}$

Tomato ringspot virus, in potato, cDNA microarray for detection of, 1248

Tomato rugose mosaic virus (ToRMV), and Begomovirus spp., Meloidogyne spp. in wild Solanum accessions, multiple resistance to, 179

Tomato spotted wilt virus (TSWV) in peanut, planting date and cultivar interactions, 891

in pepper in Taiwan, $920 \mathrm{~N}$

in potato, cDNA microarray for detection of, 1248

Tomato torrado virus (ToTV), in tomato in Australia, $486 \mathrm{~N}$ in Italy, $1172 \mathrm{~N}$

Tomato vein-greening, $376 \mathrm{~N}$, Cover photo: March

Tomato yellow leaf curl Thailand virus

(TYLCTHV), in pepper in Taiwan, 637N

Tomato yellow leaf curl virus (TYLCV) in pepper in Mexico, Tomato chino La Paz. virus co-infection, $1266 \mathrm{~N}$

in tomato

in Hawaii, $641 \mathrm{~N}$

in Mauritius, $1261 \mathrm{~N}$

and tomatillo and peppers in Guatemala, $482 \mathrm{~N}$

Tomcsányi, A., 1062N

Tomsovsky, M., 272N

Tonti, S., 1070N

Tools, Tobacco mosaic virus-contaminated, search for disinfectants for, 542

ToRMV. See Tomato rugose mosaic virus

Torre, S., 339, 1105

Torres, G. A., 1163N

Torrico, A. K., 915N

Tóth, B., $1062 \mathrm{~N}$

ToTV. See Tomato torrado virus
Townshend, J. M., 1168N

Trapero, A., $382 \mathrm{~N}$

Tredway, L. P., 751, 1374N

Trialeurodes vaporariorum (whitefly), Tomato

torrado virus on tomato, in Australia, 486N

Trichodorus primitivus, in Canada, $782 \mathrm{~N}$

Trichosanthes cucumerina (snake gourd)

Pseudoperonospora cubensis on, in

Malaysia, $642 \mathrm{~N}$

Zucchini yellow mosaic virus and Papaya ringspot virus in, in Brazil, 789N

Trifolium spp. (clover), Bean yellow mosaic

virus in, in Alaska, $372 \mathrm{~N}$

Triki, M. A., 636N

TriMV. See Triticum mosaic virus

Trioza erytreae (African citrus psyllid),

Candidatus Liberibacter asiaticus in Murraya spp. and, 528

Trioza spp. (psyllids)

T. erytreae, Candidatus Liberibacter asiaticus in sweet orange and, in Ethiopia, $482 \mathrm{~N}$

T. apicalis, and Candidatus Liberibacter solanacearum on carrots in Europe, 639N, Cover photo: May

Trisodium phosphate, Pepino mosaic virus in tomato seed and, 325

Triticum mosaic virus (TriMV), experimental

host range for, 1125

Triticum spp.

T. aestivum (wheat) cereal cyst nematode on, in China, $1505 \mathrm{~N}$

cyst nematode on, in China, 1262N deoxynivalenol in flour and bran from, different levels of Fusarium head blight resistance and, 335

Gibberella zeae on: carbendazim resistance, 1137; long-distance dispersal from corn residue, 1151

Puccinia graminis $\mathrm{f}$. sp. tritici on: sources of resistance to, 413; in South Africa, virulence and the $\mathrm{Sr} 24$ and Sr31 resistance genes, $784 \mathrm{~N}$

Puccinia striiformis f. sp. tritici on: in China, long-distance spore transport, 873; SCAR markers for detection of races CYR32 and CYR33, 221; $Y r 24$ (Yr26) gene for resistance to, $1163 \mathrm{~N}$

Puccinia triticina on: genetics of resistance, 628; physiologic specialization and, 775; resistance gene Lr32 and, in South Africa, 381N; seedling and slow rusting resistance, 45 ; virulence phenotypes and molecular genotypes, 420

Pyrenophora tritici-repentis on, novel isolates of from Arkansas, 229 soilborne pathogens of in irrigated cropping system, 61

Triticum mosaic virus in, 1125

wheat blue dwarf disease of, phytoplasma and, 977

Wheat streak mosaic virus in, water-use efficiency and, 766, 771

T. turgidum (durum wheat)

Puccinia triticina in: Lr14a gene and, 1068N; virulence phenotypes and molecular genotypes, 420

Trivedi, R. S., $1168 \mathrm{~N}$

Troisi, M., 130N

Tropaeolum majus (nasturtium), Cherry leaf roll virus in, on Amsterdam Island, 477N

Trouillas, F. P., 867, 1167N, 1267N

TRV. See Tobacco rattle virus

Tsai, C.-H., 1267N

Tsai, H.-L., $1267 \mathrm{~N}$

Tsai, W. S., 378N, 637N, 923N

Tsai, Y.-C., 1065N

Tsay, J.-G., 787N

Tseng, H.-H., $1168 \mathrm{~N}$
Tsukiboshi, T., $1064 \mathrm{~N}$

Tubbs, R. S., 898

Tuberosa, R., 420

$\beta$-Tubulin genes

in Colletotrichum cereale, $\beta$-tubulin 2 gene, thiophanate-methyl resistance and, 207

Monilinia fructicola in peach, fungicide resistance and, $1511 \mathrm{~N}$

Tunali, B., $918 \mathrm{~N}$

Turfgrass, Waitea circinata from, in British Columbia, $277 \mathrm{~N}$

Turfgrass anthracnose, resistance to thiphanatemethyl and, 207

Turini, T. A., 1118

Turner, S., $1510 \mathrm{~N}$

Turnip mosaic virus (TuMV)

in mustards, resistance to, 1290, Cover

photo: November

in watercress in Brazil, 1066N

Tuset, J. J., 636N

Tusiime, G., 109

Twizeyimana, M., 1543

TYLCTHV. See Tomato yellow leaf curl

Thailand virus

Tzanetakis, I. E., 4, 1070N, 1132

Tzavella-Klonari, K., 1314

Tzeng, S. J., 487N

Ulmus americana (elm), elm yellows

phytoplasma in, real-time PCR for, 1355

Umaharan, P., 1243

Umaña, G., 940

Unruh Snyder, L., 487N

Upadhyaya, H. D., 439

Úrbez-Torres, J. R., 717, 785N, 1267N, 1476

Uromyces spp. on chickpea and medicago, new hosts, 293 on Honckenya peploides, $279 \mathrm{~N}$

Usall, J., 1048

Ustilaginoidea virens (false smut) in rice, furrow irrigation and, 563

Vaccinium corymbosum (blueberry) Agrobacterium spp. on, in Argentina, 1064N Blueberry red ringspot virus in, in Czech Republic, $1071 \mathrm{~N}$

Neofusicoccum ribis and Lasiodiplodia theobromae on, 966

Neofusicoccum vitifusiforme on, in China, $1373 \mathrm{~N}$

Thekopsora minima on, in South Africa, $478 \mathrm{~N}$

Vacha, J., 265

Váczy, K. Z., 1169N

Váczy, Z., 1169N

Vahdat, A., 788N

Valenzuela, P. D. T., 633N, 1067N

Valkonen, J. P. T., 921N

van der Walt, L., 666

van Hoorn, A., 478N

van Niekerk, J. M., 1063N

Van Sluys, M. A., 311

van Vuuren, S. P., 244

Vandemark, G. J., 480N

Vannini, A., 272N

Vargas Jr., J. M., 922N

Varon, F., $1163 \mathrm{~N}$

Varvaro, L., 382N

Vaz, H., 1504N

Veerakone, S., 479N

Vega-Peña, S., 1266N

Vein greening. See Tomato vein-greening

Vein yellows, Apple stem pitting virus in

Bartlett pear in Argentina, 488N

Veira, R. F., 361

Velasco, L., 1507N

Ventura, J. A., 1066N, 1509N

Venturia inaequalis, in apple and crabapple in Indiana, benzimidazole resistance, 744

Vera, D. L., 488N

Vera Cruz, C. M., 311 
Verbena virus $Y$ (VVY), in verbena, 1132

Verdegaal, P., 717

Verhoeven, J. Th. J., 791N, 920N

Verma, V. S., 477N

Verticillium dahliae

on artichoke, diversity and host range, in Spain, 396

on figmarigold in Italy, 129N

on mango in Spain, 380N

on mint, 1255

in olive, defoliating and non-defoliating pathotypes, 1156

on olive in Italy, Phytophthora palmivora co-infection, $1372 \mathrm{~N}$, Cover photo:

November

on pistachio in Spain, 382N

Verticillium wilt, as threat to artichoke production, 1176

Vetten, H. J., 642N, 788N

Vetten, H.-J., 1068N

Vettraino, A. M., 272N

Vicente, J. G., 298

Vida, G., 1062N

Vigna spp.

$V$. marina (dune bean, notched cowpea), Cucumber mosaic virus in, in Taiwan, $1267 \mathrm{~N}$

$V$. radiata (mung bean sprouts), Colletotrichum acutatum on, in Taiwan, $131 \mathrm{~N}$

$V$. unguiculata (yardlong bean), Bean common mosaic virus and Cucumber mosaic virus in, in Indonesia, $478 \mathrm{~N}$

Villaescusa, F. J., 1264N

Villani, S. M., 783N

Villarino, M., 1048

Villarreal-Romero, M., 1376N

Villegas, B., 174

Vinca, annual. See Catharanthus roseus

Viršcek Marn, M., 1166N, 1171N

Visagie, C. M., 666

Visalakchi, S., 488N

Visser, B., 784N

Vitale, A., 125N, 131N, 274N, 275N, 483N, $486 \mathrm{~N}, 1509 \mathrm{~N}$

Vitale, S., 484N, 791N

Vitis vinifera (grapevine)

Arabis mosaic virus on, in Spain, $635 \mathrm{~N}$

Botryosphaeria spp. on in California, spore-trapping studies, 717 temperature and conidial germination, 1476

Botrytis cinera on, fungicides for control of, 250

Citrus exocortis viroid in, in China, 1071N

Diatrypaceae spp. on, in California, pathogenicity of, 867

Diplodia corticola on, in California, $785 \mathrm{~N}$

Grapevine fleck virus in grapevines in Washington, 784N

Grapevine leafroll-associated viruses in in Chile, $1067 \mathrm{~N}$ dodder transmission in, 471 in Spain, $1507 \mathrm{~N}$

Grapevine Syrah virus-1 in in Chile, $633 \mathrm{~N}$ in Washington, $787 \mathrm{~N}$

Lasiodiplodia crassispora on, in South Africa, $1063 \mathrm{~N}$

Neofusicoccum macroclavatum on, in New Zealand, $1504 \mathrm{~N}$

Neofusicoccum mediterraneum and Lasiodiplodia crassispora on, in California, $785 \mathrm{~N}$

phytoplasma disease in, in South Africa, $373 \mathrm{~N}$

Plasmopara viticola on early warning system for, 709 sage extract for protection, 575

Xylella fastidiosa on, in California, alfalfa as vector source and, 827
Vivanco, J. M., 1329

Voigt, T. B., 480N

Vossbrinck, C. R., 134N

Vovlas, N., 148

Vuèuroviæ, A., 703

VYY. See Verbena virus $Y$

Waitea circinata

on annual bluegrass in West Virginia, $1379 \mathrm{~N}$

on annual bluegrass in Wisconsin and Minnesota, $1165 \mathrm{~N}$

on turfgrass in British Columbia, 277N

Wakeham, A. J., 851

Wallace, R. W., $481 \mathrm{~N}$

Wallis, K. M., 345

Walnut. See Juglans regia

Wang, B., 221, 1508N

Wang, G. P., 1071N

Wang, H., 378N, 873, 977

Wang, H. Y., 45

Wang, H.-C., 551

Wang, I.-C., $921 \mathrm{~N}$

Wang, J. H., 280N, 641N, 782N

Wang, J. T., 637N, 923N

Wang, L., 634N

Wang, L. H., 782N

Wang, N., 915N

Wang, S.-L., 1341

Wang, W.-L., 787N

Wang, X., 1441

Wang, X. F., 375N, 922N

Wang, X. X., 1508N

Wang, Y., 881

Wang, Y. C., 378N

Wang, Y. L., 1510N

Wang, Z. Y., 1503N

Ward, L. I., $479 \mathrm{~N}$

Washingtonia robusta (Mexican fan palm),

Fusarium oxysporum $\mathrm{f}$. sp. palmarum, in

Florida, 31

Watanabe, K., 812

Watercress. See Nasturtium officinale

Watering regime, Bursaphelenchus spp. on Scots pine and, 1055

Watermelon. See Citrullus lanatus

Waters, T. D., 236

Water-use efficiency, Wheat streak mosaic virus in wheat and, 766, 771

Waxman, K. D., 1151

Way, M. O., 639N

WBD. See Wheat blue dwarf disease

Wechter, W. P., 132N

Weeping cypress. See Cupressus funebris

Wei, G., 959

Wei, J. H., 918N, 1508N

Weiland, J. E., 1009

Wen, A., 659

Wen, R.-H., $1505 \mathrm{~N}$

Weng, B.-C., 787N

West, C. P., 381N

Wheat. See Triticum aestivum; Triticum turgidum (durum wheat)

Wheat blue dwarf disease (WBD), identification of phytoplasma associated with, 977

Wheat curl mites. See Aceria tosichella

Wheat streak mosaic virus (WSMV) isolation of Triticum mosaic virus from, 1125 in wheat, water-use efficiency and, 766, 771

Wheele, G. S., $1165 \mathrm{~N}$

Wheeler, T. A., $481 \mathrm{~N}$

White leaf streak, Mycovellosiela oryzae on rice in Texas, 639N

White lupine. See Lupinus albus

White oak. See Quercus alba

White pine blister rust (WPBR), Cronartium ribicola in gooseberry, comparative infectivity of asciospores and uredinisopores, 461

Whitefly. See Bemisia argentifolii; Bemisia tabaci; Trialeurodes vaporariorum

Whitworth, J., 1384
Whole-cell fatty acid (WCFA) measurements, in planta quantification of Plasmodiophora brassicae, 432

Wick, R., 484N

Wicker, E., $1264 \mathrm{~N}$

Widana Gamage, S. M. K., 1070N

Wieczorek, P., 920N

Wilber, L. J., 378N

Williams, D. W., 480N

Williams, S., 781N

Williamson, S. M., 634N

Wilson, C., 528

Wingfield, M. J., 1143

Winter, S., 276N

Winter wheat. See Triticum aestivum

Wipf-Scheibel, C., 1378N

Witloof chicory. See Cichorium intybus

Wong, F. P., 207, 919N, 1165N

Wong, M. Y., 642N

Wood, A., 478N

Woodland sage. See Salvia nemorosa

Woods, D. M., 174

Woodward, J. E., 792N, 1377N

woody nightshade. See Solanum dulcamara

Workneh, F., 659, 766, 771

Worrall, J. J., 115

Wright, A. F., 966

Wright, D. L., 258, 1336

Wright, R. J., 792N

Wu, H. Y., 1064N

Wu, H.-W., 134

Wu, J., 87, 1137

Wu, L. F., 280N

Wu, X. L., $1171 \mathrm{~N}$

Wu, X. W., 280N

Wylie, S. J., 1264N

Xanthomonas spp.

in grapefruit in Florida, wind speed and dispersal downwind from infected trees, 725

in pepper and tomato, genetic and

pathological diversity in, 993

$X$. arboricola

on bell pepper in Korea, 271N on peach, oxytetracycline for, 1213

$X$. axonopodis in Anthurium andraeanum, resistance to 1243

$X$. campestris

in banana, PCR assay for detection of, 109 on cauliflower and cabbage in Nepal, 298 on lettuce in South Korea, 790N

$X$. euvesicatoria, on carrot and pepper in Granada, $1264 \mathrm{~N}$

$X$. gardneri, on tomato in Pennsylvania, 638N

$X$. hortorum, on carrot in Mauritius, 1069N

$X$. oryzae, genomics-based marker development for, 311

Xia, X. C., 45

Xiang, J., 977

Xiang, Y., 977

Xiao, C. L., 604

Xie, G. L., $482 \mathrm{~N}$

Xie, X. -W., 127N

Xie, X.-W., 1377N

Xie, Y. J., 1143

Xing, X. P., 1505N

Xiong, Y., 637N

$\mathrm{Xu}, \mathrm{D} ., 485 \mathrm{~N}$

$\mathrm{Xu}, \mathrm{H} ., 1384$

$\mathrm{Xu}, \mathrm{P} ., 87$

Xu, W. X., 1071N

Xue, A. G., 87

Xue, L., 796

Xyleborus glabratus (redbay ambrosia beetle) and Raffaelea lauricola on redbay in Mississippi, 634N

Xylella fastidiosa

on oleander in Louisiana, $274 \mathrm{~N}$

on pecan, insect transmission of, 465 and Pierce's disease in California, 827 
Yakabe, L. E., 320

Yam, throughhill. See Dioscorea nipponica

Yamaguchi, J., 329

Yamamoto, P., 244

Yamauchi, H., 335

Yan, H., 482N

Yan, L., 922N

Yan, X., 376N

Yang, C. M., $918 \mathrm{~N}$

Yang, F. Y., 922N

Yang, H. R., 128N

Yang, Q. H., 351

Yang, S. Y., 637N

Yang, W. X., 45

Yang, X. B., 796, 873

Yang, X. M., 782N

Yao, K. S., 481N

Yardlong beans. See Vigna unguiculata

Ye, W., 782N

Ye, W. X., $1262 \mathrm{~N}$

Yeater, K. M., 570

Yeh, S.-D., 1341

Yellow leaf disease (YLD), in arecanut palm in

India, phytoplasma infection and, $1376 \mathrm{~N}$

Yellow starthistle. See Centaurea solstitialis

Yi, K. S., 1373N

Yi, L., 375N

Yin, W., 881

Yin, Y., 1137

Yokomi, R. K., 75, 482N

Yoshida, S., 812

Young, H. M., 1379N

Young, J. R., 207, 75

Yr24 (Yr26) gene, Puccinia striiformis f. sp. tritici in wheat, resistance to, $1163 \mathrm{~N}$

Yu, C. H., 1164N

Yu, L., 1373N

$\mathrm{Yu}, \mathrm{Q}, \mathrm{7} \mathrm{2} 2 \mathrm{~N}, 1510 \mathrm{~N}$

Yu, S. H., 482N

Yu, T.-A., 1341

Yu, X. F., 1373N

Yu, Z. Z., 271N

Yuan, H. X., 1505N
Yun, H. Y., 279N

Zaid, A. M., $916 \mathrm{~N}$

Zambino, P., $1510 \mathrm{~N}$

Zambolim, E. M., 1378N

Zambolim, L., 1378N

Zare, R., 375N, 642N

Zazzerini, A., $372 \mathrm{~N}$

Zea mays (corn)

Cephalosporium maydis on, in Portugal and Spain, 379N

Clavibacter michiganensis subsp.

nebraskensis in, in Minnesota, 1064N

Gibberella zeae in wheat, long-distance dispersal from corn residue, 1151

Pantoea ananatis on, in Argentina, 487N

Pantoea stewartii subsp. stewartii on, host resistance and thresholds for use of seedtreatment insecticides, 1111, Cover photo: September

Phytophthora sansomeana on, in Ohio, wilting and stunting, $125 \mathrm{~N}$

processing of, managing foliar diseases of with strobilurin fungicides, 213

with simulated hail damage, effect of foliar fungicides on, 83

Stenocarpella macrospora on, in Illinois, $1262 \mathrm{~N}$

Sugarcane mosaic virus and Maize dwarf mosaic virus in, 1093

Zebra chip (ZC) disease, 659

Zelaya-Molina, L. X., 125N

Zemetra, R., 918N

Zeng, D. X., 1171N

Zhang, B., 221

Zhang, G. R., 1262N

Zhang, H., 641N

Zhang, J., 87

Zhang, L., 132N

Zhang, L. J., 45

Zhang, M., 1064N

Zhang, N., 1265N

Zhang, Q., 915N
Zhang, R. Y., 379N

Zhang, S., 87

Zhang, X. J., 1503N

Zhang, Y., 376N

Zhang, Y. P., 280N

Zhang, Z., 881, 918N, 1510N

Zhang, Z. K., 132N

Zhang, Z.-P., 130N

Zhang, Z. Y., 1163N

Zhao, G.-H., $1166 \mathrm{~N}$

Zhao, S., $1265 \mathrm{~N}$

Zhao, W. J., 640N

Zhao, Y.-J., 127N

Zheng, J., 376N

Zheng, L., 1231

Zheng, X., 881

Zheng, X. B., 378N

Zheng, Y., $1261 \mathrm{~N}$

Zheng, Y. X., 484N

Zheng, Y.-X., 920N, 1263N

Zhi, H. J., 351

Zhou, C. Y., 375N, 637N, 922N

Zhou, M.-G., 551

Zhou, X. D., 1143

Zhou, X. G., 92, 639N

Zhou, Y. K., 1508N

Zhu, F. X., $1511 \mathrm{~N}$

Zhu, S. F., 640N

Zhu, W. M., 485N

Zhu, X. Q., $478 \mathrm{~N}$

Zhu, Y. Z., $1172 \mathrm{~N}$

Zhuo, K., 271N

Zingiber officinale (ginger), Ralstonia

solanacearum in, essential oils and, 521

Zlatohlavek, A., 272N

Zucchini. See Cucurbita pepo

Zucchini yellow mosaic virus (ZYMV) in cucurbits in Ivory Coast, 1378N

in cucurbits in Mali, 923N

in snake gourd in Brazil, 789N

Zucchini yellow mosaic virus (ZYMV),

transgenic melon for resistance to, 1341

Zunnoon-Khan, S. 